\title{
OPA-based bifunctional linker for protein labeling and
}

profiling

Qing Zhang ${ }^{\ddagger}$, a Yue Zhang ${ }^{\ddagger}$, a Heng Liu ${ }^{\mathrm{a}}$, Hoi Yee Chow ${ }^{\mathrm{a}}$, Ruijun Tian ${ }^{\mathrm{b}}$, Yi Man Eva Fung ${ }^{\text {a }}$, Xuechen $\mathrm{Li}^{*}$, a

${ }^{a}$ Department of Chemistry, State Key Laboratory of Synthetic Chemistry, The University of Hong Kong, Hong Kong, P. R. China, SAR

${ }^{\mathrm{b}}$ Department of Chemistry, Southern University of Science and Technology, Shenzhen, P. R. China 


\section{Table of content}

\section{Biological assays}

$\begin{array}{ll}\text { 1.1 Materials } & \text { S3 }\end{array}$

$\begin{array}{ll}\text { 1.2 OPA-alkyne bioconjugation reaction } & \text { S3 }\end{array}$

$\begin{array}{ll}1.3 \text { Turbidity assay to test protein aggregation } & \text { S5 }\end{array}$

$\begin{array}{ll}\text { 1.4 OPA-alkyne probes for protein modification followed by } & \text { S7 }\end{array}$

$\begin{array}{ll}\text { click reaction in one-pot } & \text { S9 }\end{array}$

$\begin{array}{ll}\text { 1.5 Modification sites identification after OPA-NH-alkyne } & \text { S10 }\end{array}$

labeling in recombinant lysozyme $\mathrm{C}$

$\begin{array}{ll}\text { 1.6 Cultivation of bacteria and whole proteome labeling } & \text { S13 }\end{array}$

$\begin{array}{ll}\text { 1.7 Streptavidin affinity enrichment of biotinylated proteins } & \text { S17 }\end{array}$

$\begin{array}{ll}\text { 1.8 MS sample preparation } & \text { S17 }\end{array}$

$\begin{array}{ll}\text { 1.9 MS analysis } & \text { S18 }\end{array}$

$\begin{array}{ll}\text { 2.0 Data analysis } & \text { S18 }\end{array}$

$\begin{array}{lr}\text { II. Synthesis part } & \text { S20 }\end{array}$

$\begin{array}{lr}\text { 2.1 Materials and Methods } & \text { S20 }\end{array}$

$\begin{array}{ll}2.2 \text { General procedures for RP-LCMS detection } & \text { S20 }\end{array}$

$\begin{array}{ll}\text { 2.3 Synthesis of OPA-alkyne bifunction linkers } & \text { S20 }\end{array}$

$\begin{array}{lr}\text { 2.3.1 Synthesis of methyl 3-(3,4-di(1,3-dioxolan-2-yl) phenyl) } & \text { S20 }\end{array}$

propanoate

$\begin{array}{lr}\text { 2.3.2 Synthesis of 4-(3-(prop-2-yn-1-ylamino) propyl) } & \text { S21 }\end{array}$

phthalaldehyde hydrochloride

$\begin{array}{ll}\text { 2.3.3 Synthesis of 4-(3-(prop-2-yn-1-yloxy) propyl) } & \text { S23 }\end{array}$

phthalaldehyde

$\begin{array}{ll}\text { 2.3.4 Synthesis of 4-(but-3-yn-1-yl) phthalaldehyde } & \text { S25 }\end{array}$

$\begin{array}{lr}\text { 2.3.5 Synthesis of OPA-biotin linker } & \text { S26 }\end{array}$

$\begin{array}{ll}\text { III. NMR Spectra } & \text { S29 }\end{array}$

$\begin{array}{ll}\text { IV. Reference } & \text { S40 }\end{array}$ 


\section{Biological assays}

\subsection{Materials}

Lysozyme C from chicken egg white and ribonuclease A from bovine pancreas were purchased from Sigma-Aldrich. All chemical materials (Sigma-Aldrich, GL Biochem) were used without further purification. All solvents were reagent grade or HPLC grade (RCI or DUKSAN). Dry dichloromethane $\left(\mathrm{CH}_{2} \mathrm{Cl}_{2}\right)$ was distilled from calcium hydride. Analytical TLC plate was performed on Silica-gel 60 (0.040-0.063 mm). ${ }^{1} \mathrm{H}$ and ${ }^{13} \mathrm{C}$ NMR spectra were recorded on Bruker Avance DRX 300 FT-NMR spectrometer at $300 \mathrm{MHz}$ for ${ }^{1} \mathrm{H}$ NMR and $75.47 \mathrm{MHz}$ for ${ }^{13} \mathrm{C}$ NMR or Bruker Avance DRX 400 FT-NMR spectrometer at $400 \mathrm{MHz}$ for ${ }^{1} \mathrm{H}$ NMR and $100 \mathrm{MHz}$ for ${ }^{13} \mathrm{C}$ NMR.

Rhodamine- $\mathrm{N}_{3}$ was synthesized according to the previous report ${ }^{[1]}$.

Tris[(1-benzyl-1H-1,2,3-triazol-4-yl)methyl]amine (TBTA) and other related chemicals, not noted above, were purchased from Sigma-Aldrich (St. Louis, MO, U.S.). NHS-biotin (CAS: 35013-72-0) was purchased from J\&K. The structures of some key chemicals were shown in Scheme S1. Streptavidin agarose and BCA protein assay kit were purchased from Thermo Scientific (Waltham, MA, U.S.).

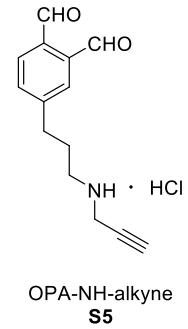

S5

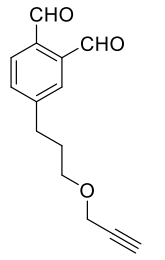

OPA-O-alkyne

s8

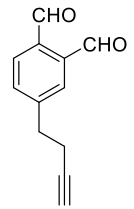
OPA-CH
S10
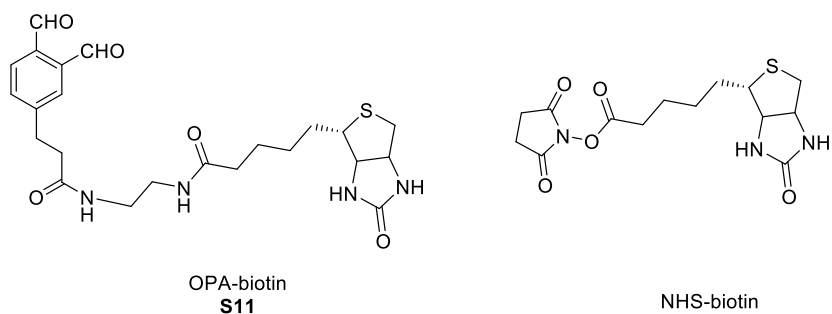

NHS-biotin

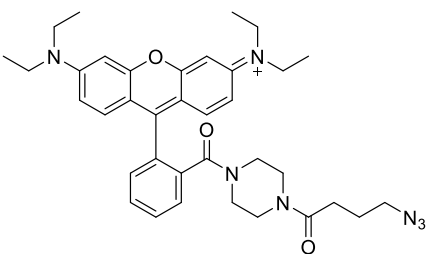

Rhodamine- $\mathrm{N}_{3}$

Scheme S1. Chemical structures of key probes. 
Table S1. Bacteria strains and abbreviations

\begin{tabular}{cccccccc}
\hline \multicolumn{2}{c}{$\boldsymbol{P}$. aeruginosa } & \multicolumn{2}{c}{ A. baumannii } & \multicolumn{2}{c}{ V. vulnificus } & \multicolumn{2}{c}{ K. pneumoniae } \\
\hline Strain & Serotype & Strain & Abbreviation & Strain & Abbreviation & Strain & Abbreviation \\
\hline PAO1 & O5 & 00.1859 & Ab1 & Vv002 & Vv2 & HKU_1 & Kp1 \\
PA1244 & O7 & 00.2086 & Ab2 & Vv003 & Vv3 & HKU_2 & Kp2 \\
& & 00.191 & Ab3 & & & & \\
& 00.610 & Ab7 & & & & & \\
& & 00.2119 & Ab8 & & & & \\
\end{tabular}




\subsection{OPA-alkyne bioconjugation reaction}

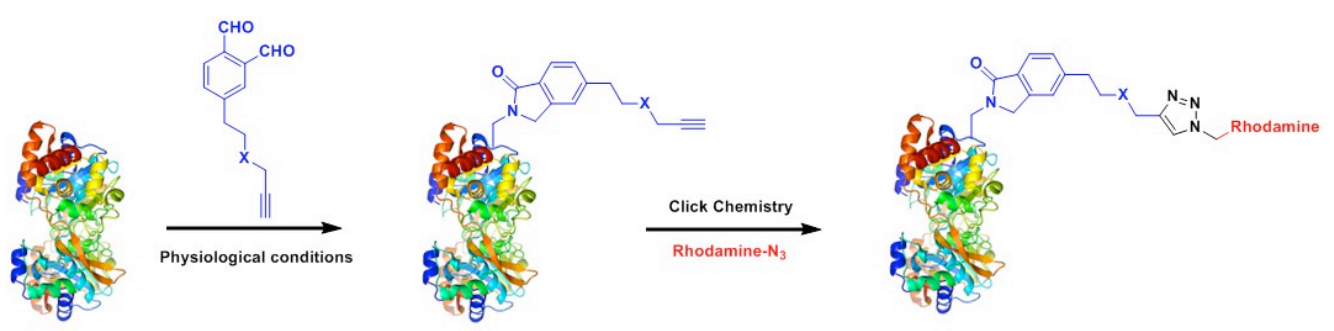

Target protein was chosen to conjugate with different equivalent OPA-alkyne linkers. In the PBS buffer solution ( $\mathrm{pH}$ 7.4), different OPA-alkyne probes with different equivalents were incubated separately with the same respective concentration $(0.1 \mathrm{mM})$ of the model protein for $45 \mathrm{~min}$ at room temperature, and each sample was quenched with $5 \mu \mathrm{L}$ of $2 \mathrm{M}$ glycine solution. The sample solution after desalting was ready for MALDI-TOF analysis.

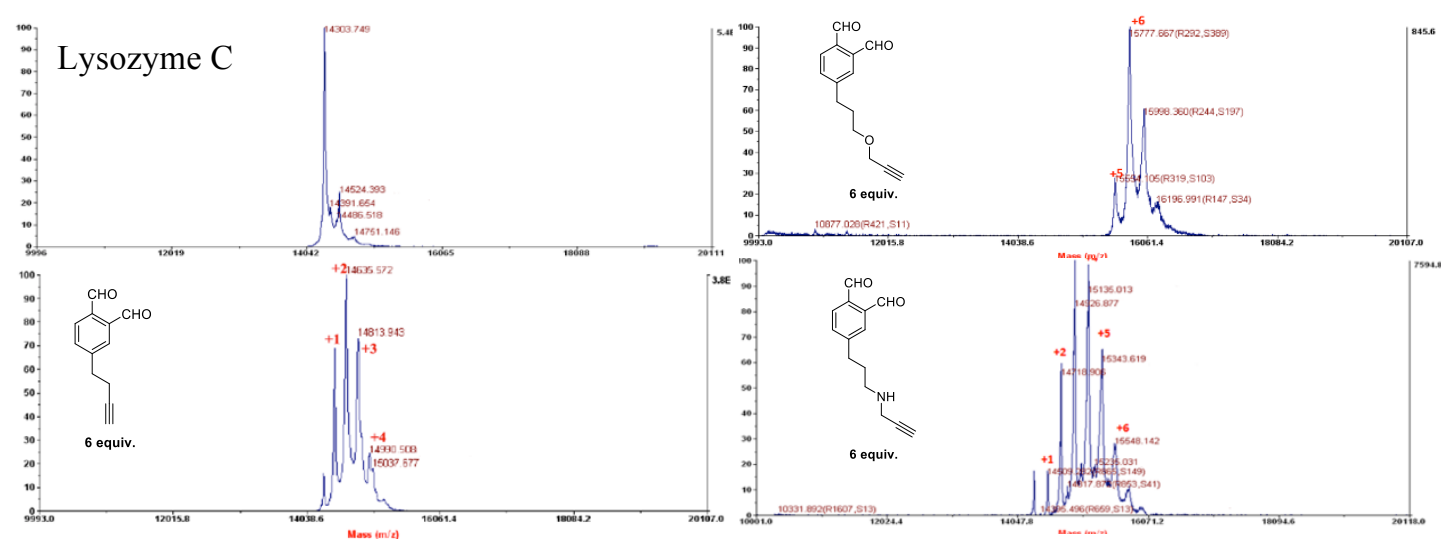

Figure S1. MALDI-TOF analysis of lysozyme C labeled with OPA-alkyne probes (6 equiv.).

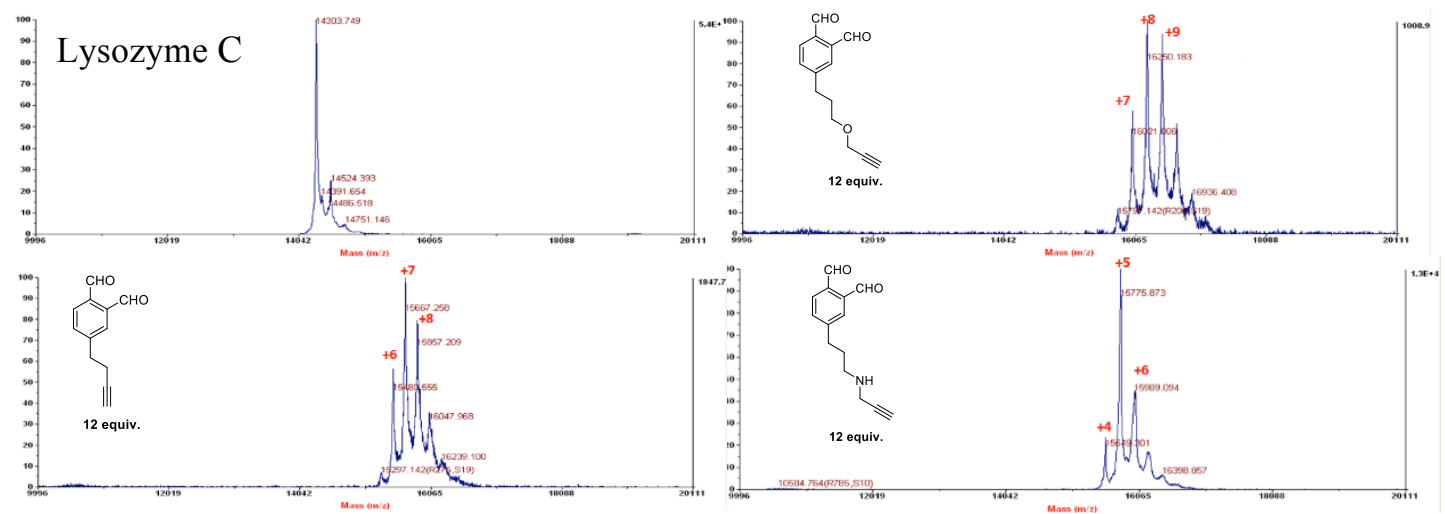

Figure S2. MALDI-TOF analysis of lysozyme C labeled with OPA-alkyne probes (12 equiv.). 

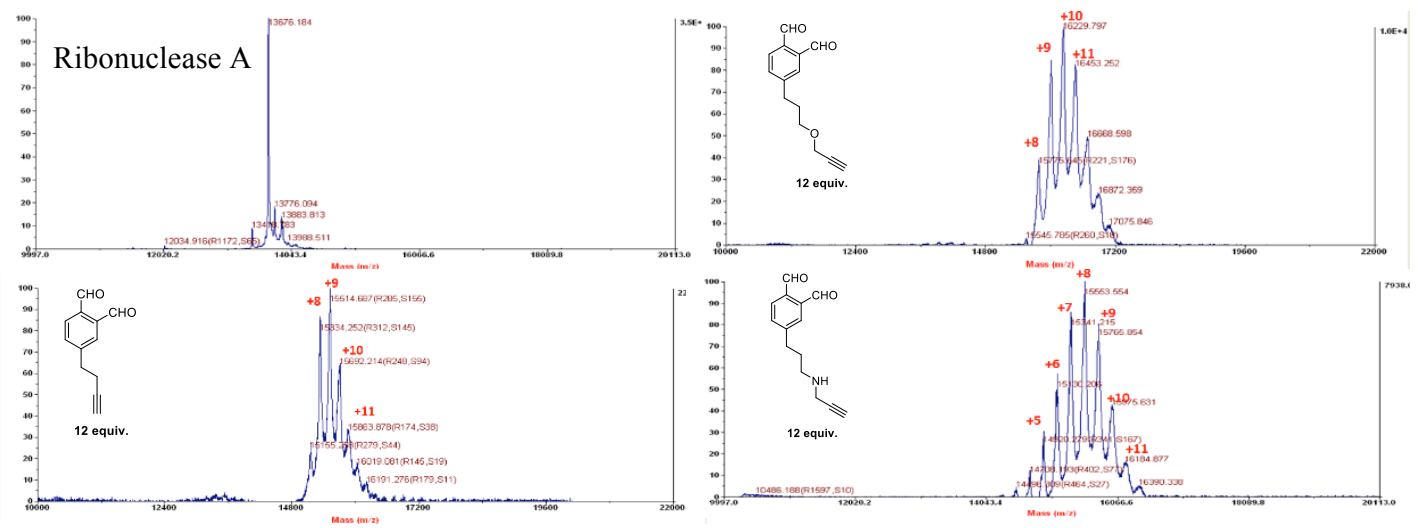

Figure S3. MALDI-TOF analysis of ribonuclease A labeled with OPA-alkyne probes (11 equiv.).

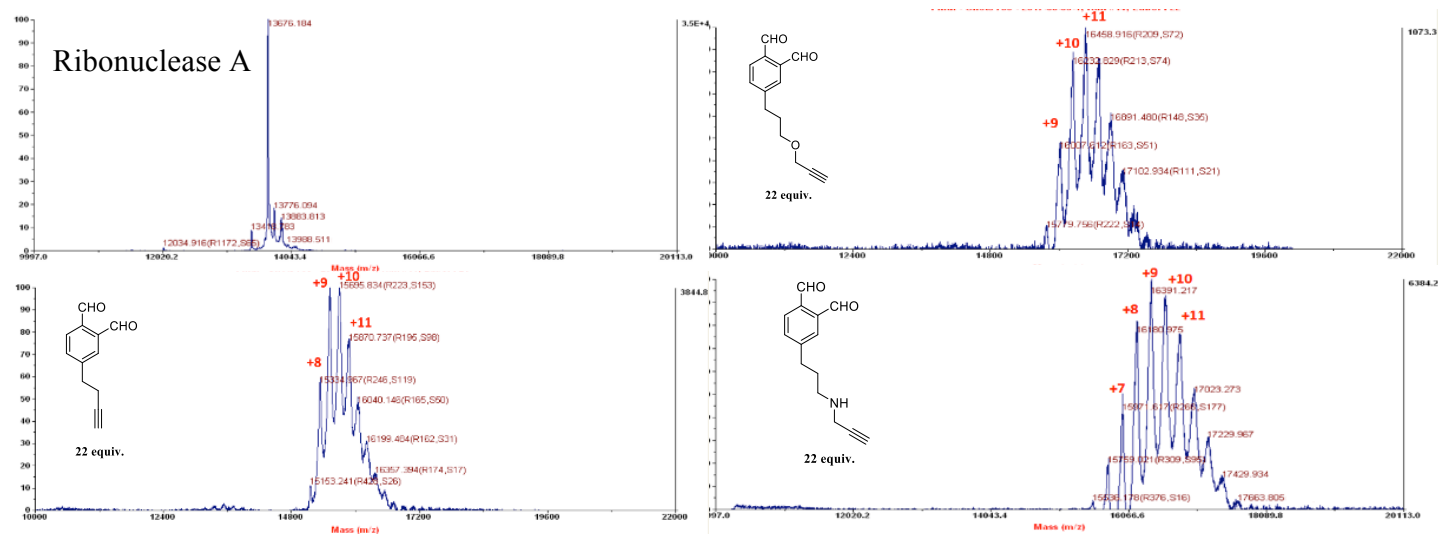

Figure S4. MALDI-TOF analysis of ribonuclease A labeled with OPA-alkyne probes (22 equiv.). 


\subsection{Turbidity assay to test protein aggregation}

Target proteins (lysozyme C from chicken egg white and ribonuclease A from bovine pancreas) were used to conjugate with different OPA-alkyne linkers.

In PBS buffer solution (500 $\mu \mathrm{L})(\mathrm{pH} 7.4)$, the OPA-alkyne probes ( 3 eq., 6 eq. and 12 eq.) were incubated separately with lysozyme $\mathrm{C}$ (final concentration: $0.1 \mathrm{mM}$ ) for $45 \mathrm{~min}$ at room temperature. After $45 \mathrm{~min}, 5 \mu \mathrm{L}$ of $2 \mathrm{M}$ glycine solution was added to quench OPA-labeling reaction. Then the solution was transfer to $96-$ well plate and followed by determining the solution turbidity under different wavelengths (300 nm and $450 \mathrm{~nm}$ ).

In PBS buffer solution $(500 \mu \mathrm{L})(\mathrm{pH} 7.4)$, the OPA-alkyne probes (6 eq., 12 eq. and 24 eq.) were incubated separately with ribonuclease A (final concentration: $0.1 \mathrm{mM}$ ) for $45 \mathrm{~min}$ at room temperature. After $45 \mathrm{~min}, 5 \mu \mathrm{L}$ of $2 \mathrm{M}$ glycine solution was added to quench OPA-labeling reaction. Then the solution was transfer to 96 -well plate and followed by determining the solution turbidity under different wavelengths (300 $\mathrm{nm}$ and $450 \mathrm{~nm}$ ).

The absorbance under different wavelengths was read by SYNERGY HTX multi-mode reader (BioTek). Each sample was replicated three times. The static data was analyzed by Graphpad Prism 6. (*: P value $<0.05, * *$ : P value $<0.01, * * *$ : P value $<0.001$.)

A

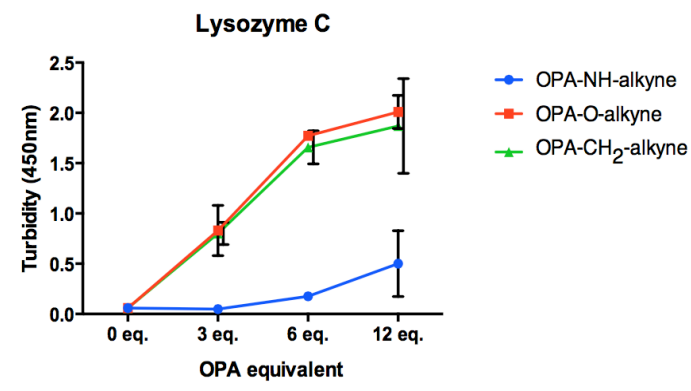

B

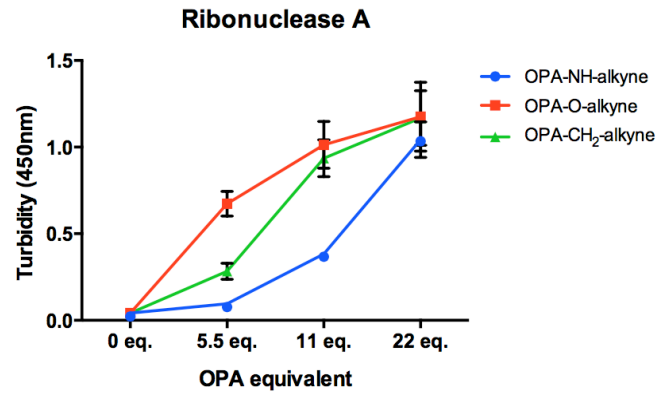

Figure S5. Influence of protein aggregation after labeled by different OPA-alkyne linkers (450 $\mathrm{nm})$.

In PBS buffer solution (500 $\mu \mathrm{L})(\mathrm{pH} 7.4)$, the OPA-NH-alkyne probes ( 3 eq., 6 eq. and 12 eq.) and OPA-biotin (3 eq., 6 eq. and 12 eq.) were incubated separately with lysozyme $\mathrm{C}$ (final concentration: $0.1 \mathrm{mM}$ ) for $45 \mathrm{~min}$ at room temperature. After $45 \mathrm{~min}, 5 \mu \mathrm{L}$ of $2 \mathrm{M}$ glycine solution was added to quench OPA-labeling reaction. Then the solution was transfer to 96-well plate and followed by determining the solution turbidity under $300 \mathrm{~nm}$ wavelength. 
Lysozyme C

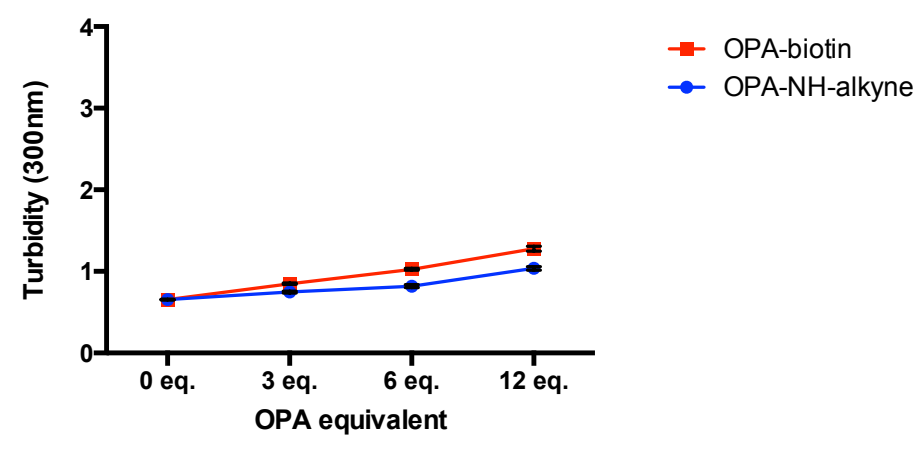

Figure S6. Turbidity study of OPA-biotin and OPA-NH-alkyne after labeling lysozyme C. 


\subsection{OPA-alkyne probes for protein modification followed by click reaction in one-pot}

After the OPA-NH-alkyne mediated labeling of target proteins or cell lysates, $100 \mu \mathrm{M}$ rhodamine azide solution was added into the mixture, followed by $1 \mathrm{mM}$ TCEP solution and $100 \mu \mathrm{M}$ TBTA solution in the same pot. After mixing all ingredients, the Click reaction was initiated by addition of $1 \mathrm{mM} \mathrm{CuSO}_{4}$ and incubated at room temperature for $2 \mathrm{~h}$. The reaction mixture was then denatured by the sample loading buffer, heated at $95{ }^{\circ} \mathrm{C}$ or $10 \mathrm{~min}$, and resolved by $10 \%$ or $12 \%$ SDS-PAGE. The gel was imaged under Bio-Rad ChemiDoc imaging system and then stained by Coomassie blue as the standard.
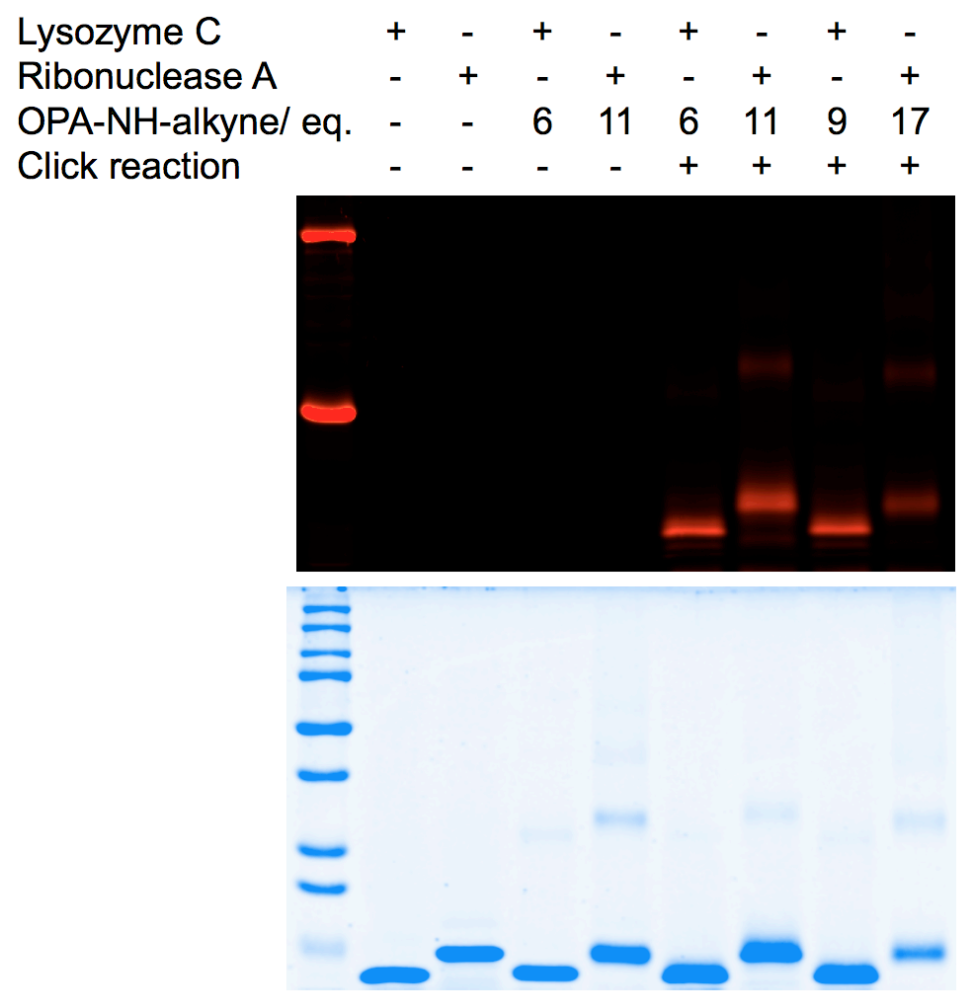

Figure S7. Protein covalent labeling by OPA-NH-alkyne. A. Fluorescence scanning of the protein covalent labeling by OPA-NH-alkyne followed by click with rhodamine- $\mathrm{N}_{3}$. B. Coomassie blue staining of the protein covalent labeling OPA-NH-alkyne followed by click with rhodamine- $\mathrm{N}_{3}$. 
1.5 Modification sites identification after OPA-NH-alkyne labeling in recombinant lysozyme C

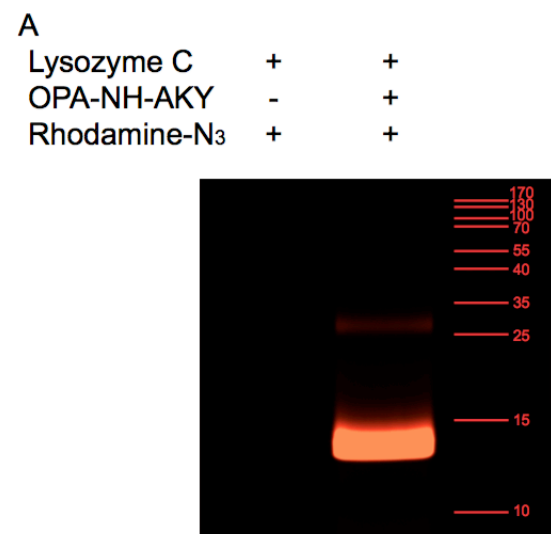

Rhodamine
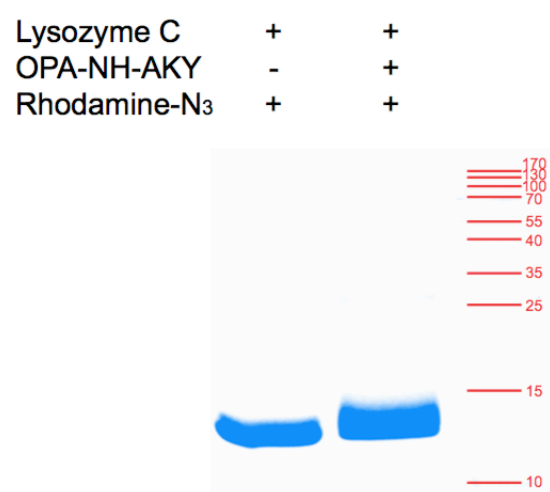

Coomassie blue
B

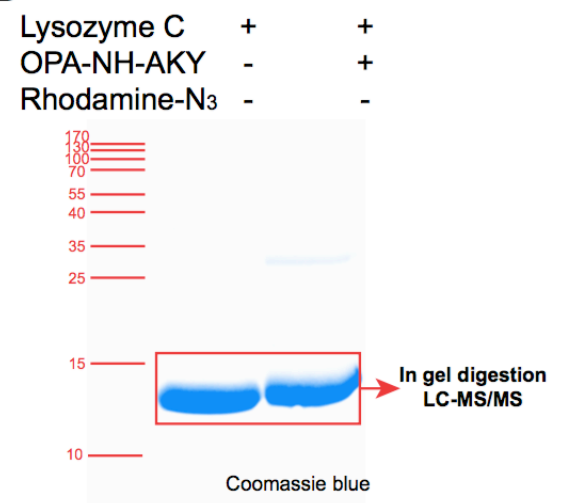

C

- C C

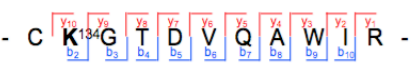

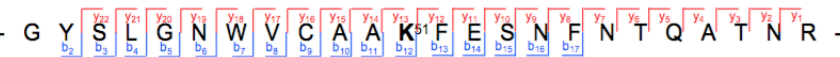

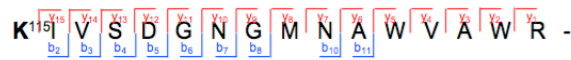

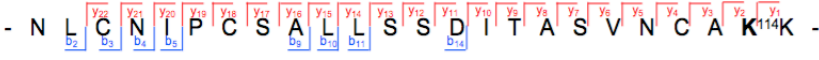

Figure S8. Covalent labeling of recombinant lysozyme C by OPA-NH-alkyne. A. Demonstration of covalent labeling of lysozyme $\mathrm{C}$ by fluorescence scanning after clicking with rhodamine- $\mathrm{N}_{3}$. B, C. Modification sites identified after OPA-NH-alkyne labeling in recombinant lysozyme C. 


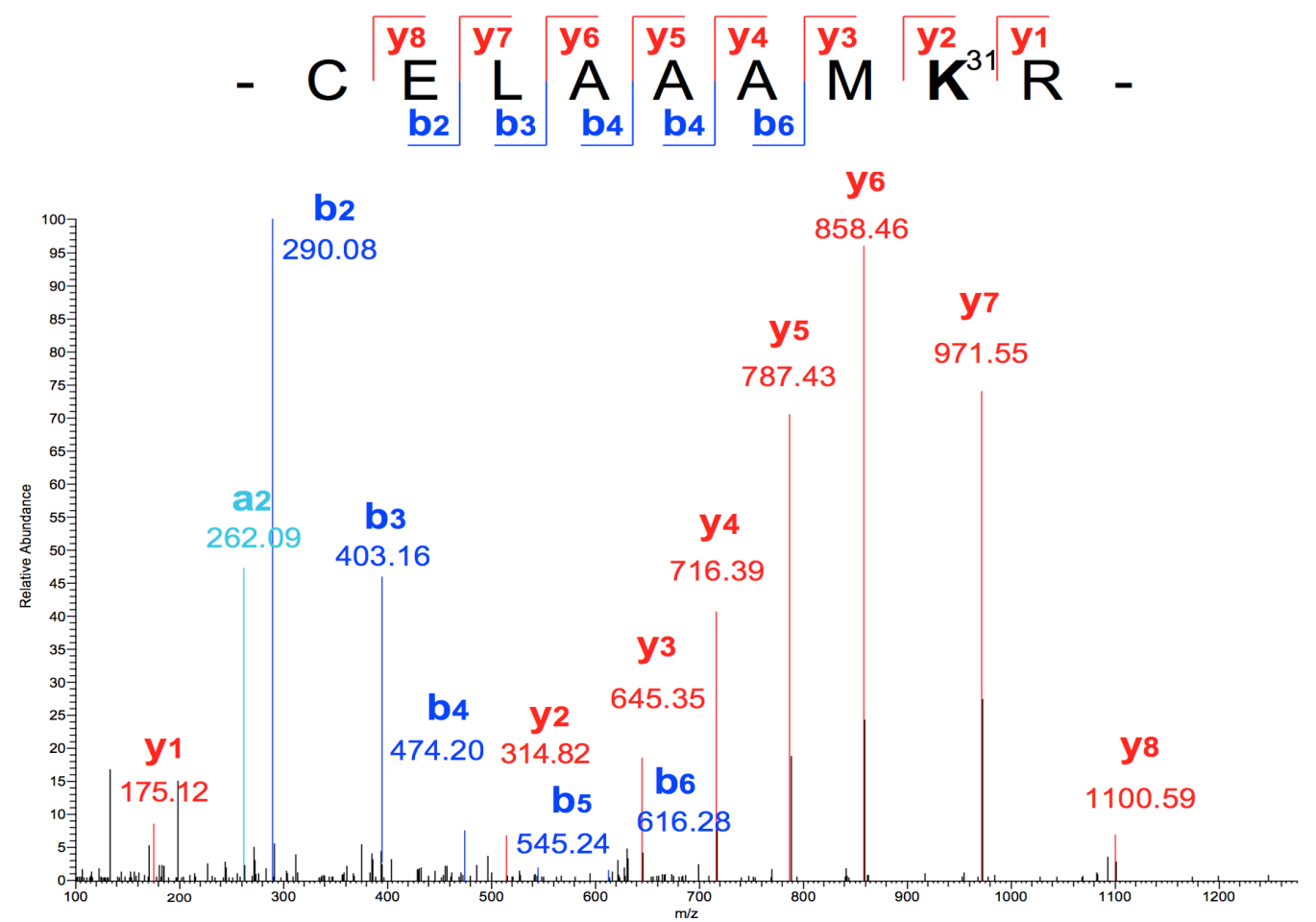

Figure S9. Covalent modification of lysine 31 by OPA-NH-alkyne.

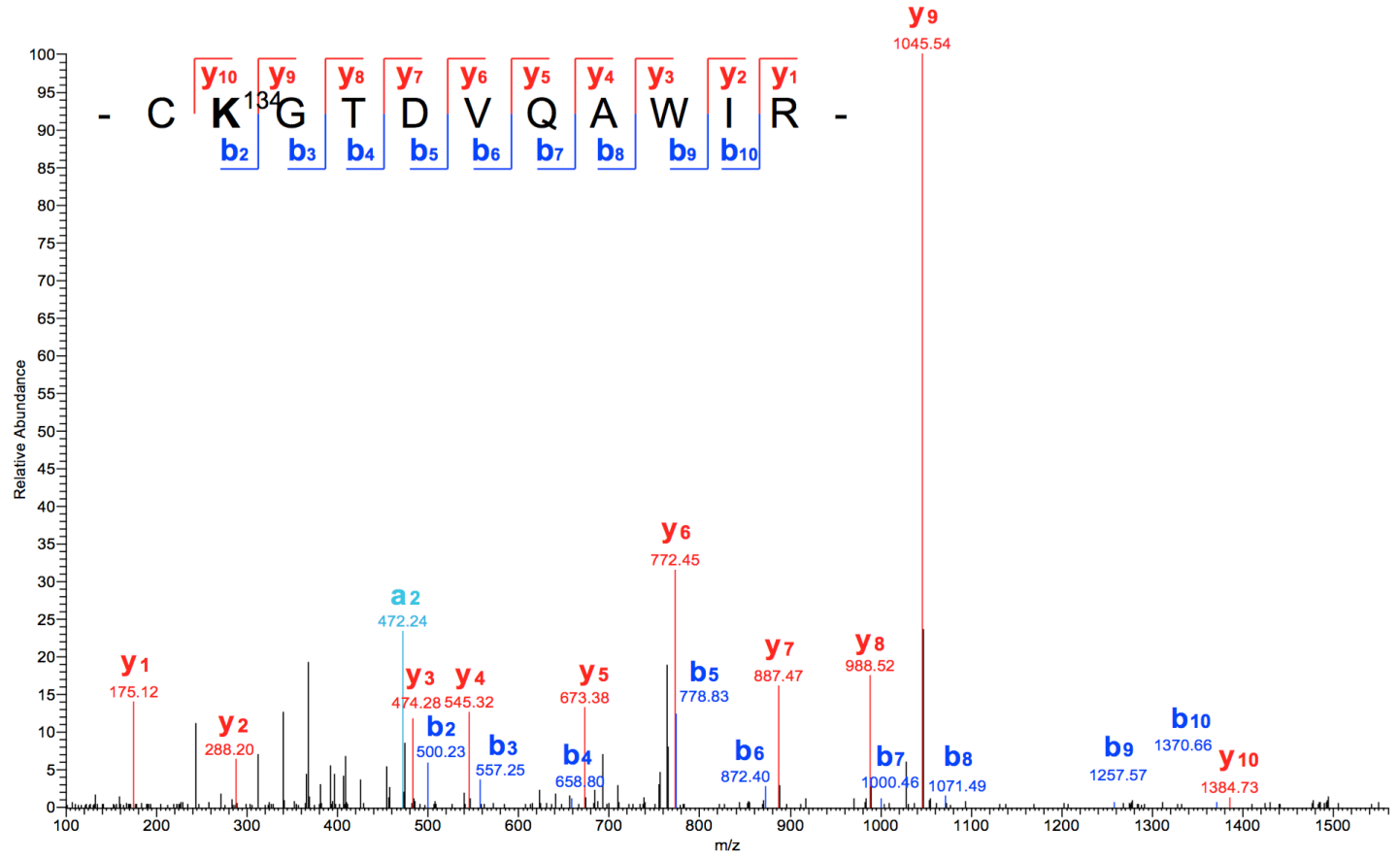

Figure S10. Covalent modification of lysine 134 by OPA-NH-alkyne. 


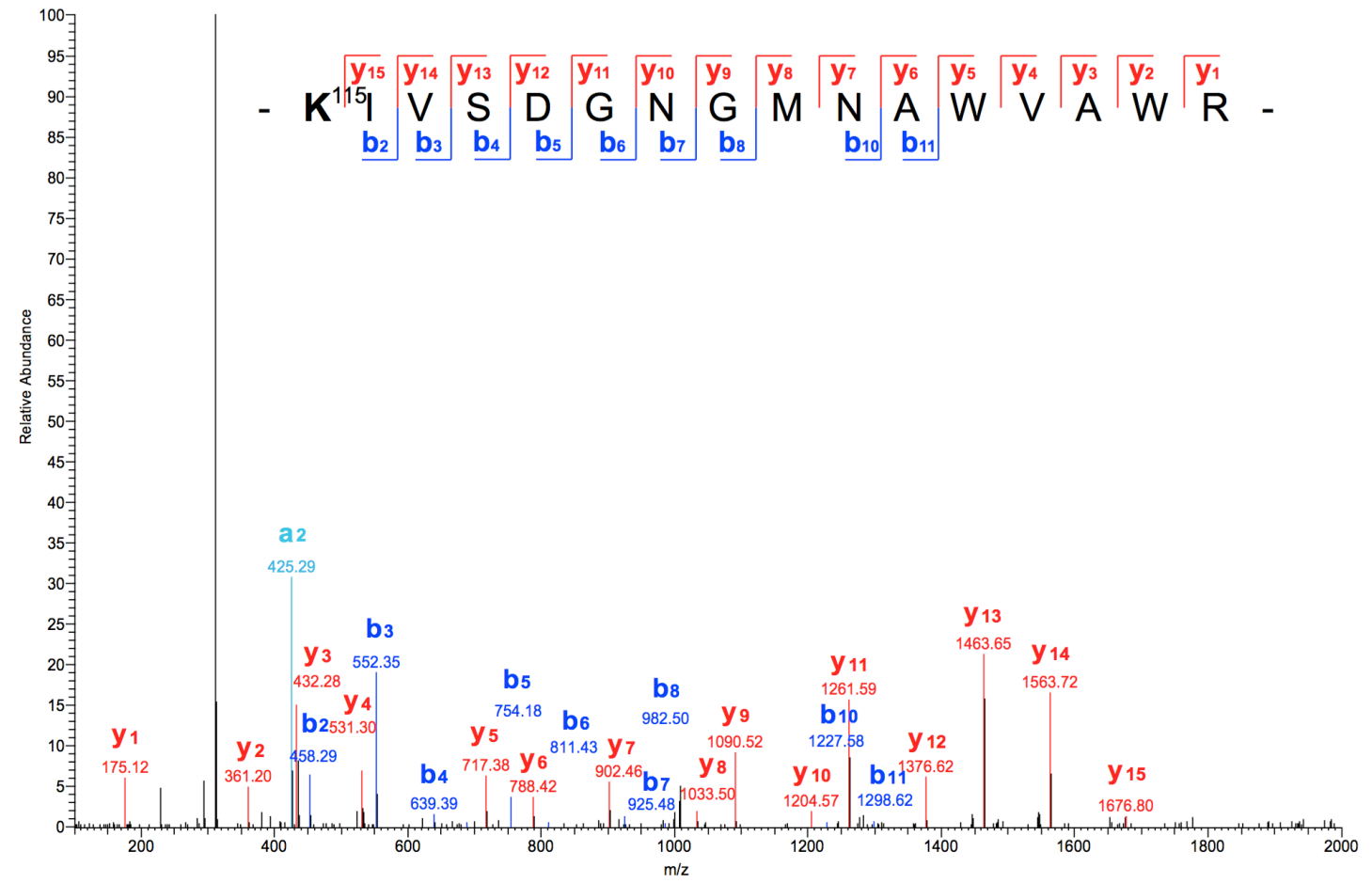

Figure S11. Covalent modification of lysine 115 by OPA-NH-alkyne.

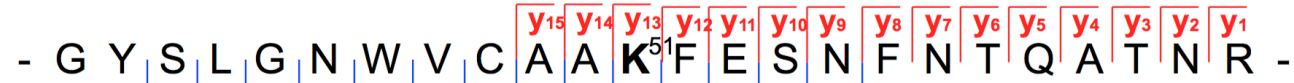

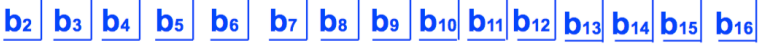

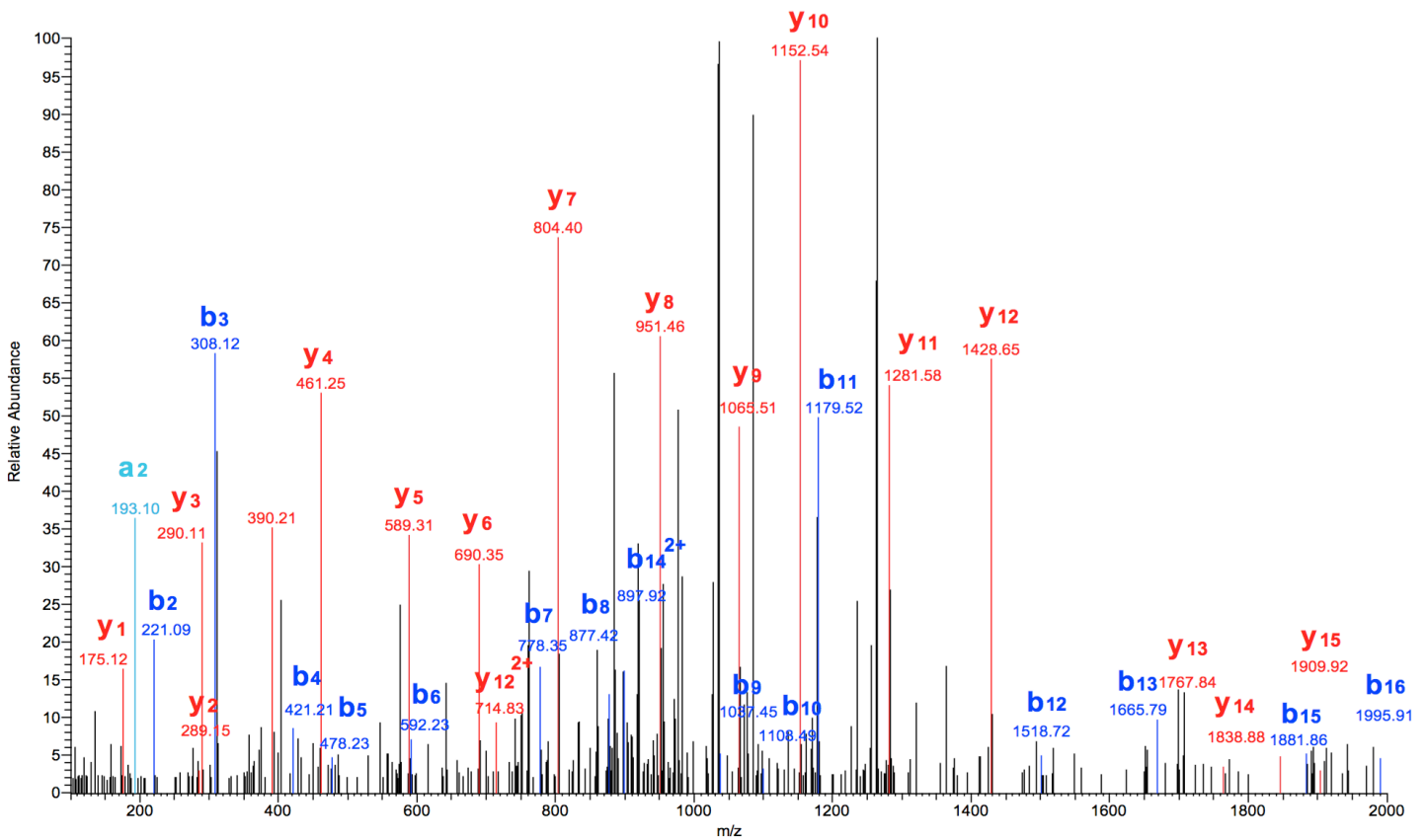

Figure S12. Covalent modification of lysine 51 by OPA-NH-alkyne. 


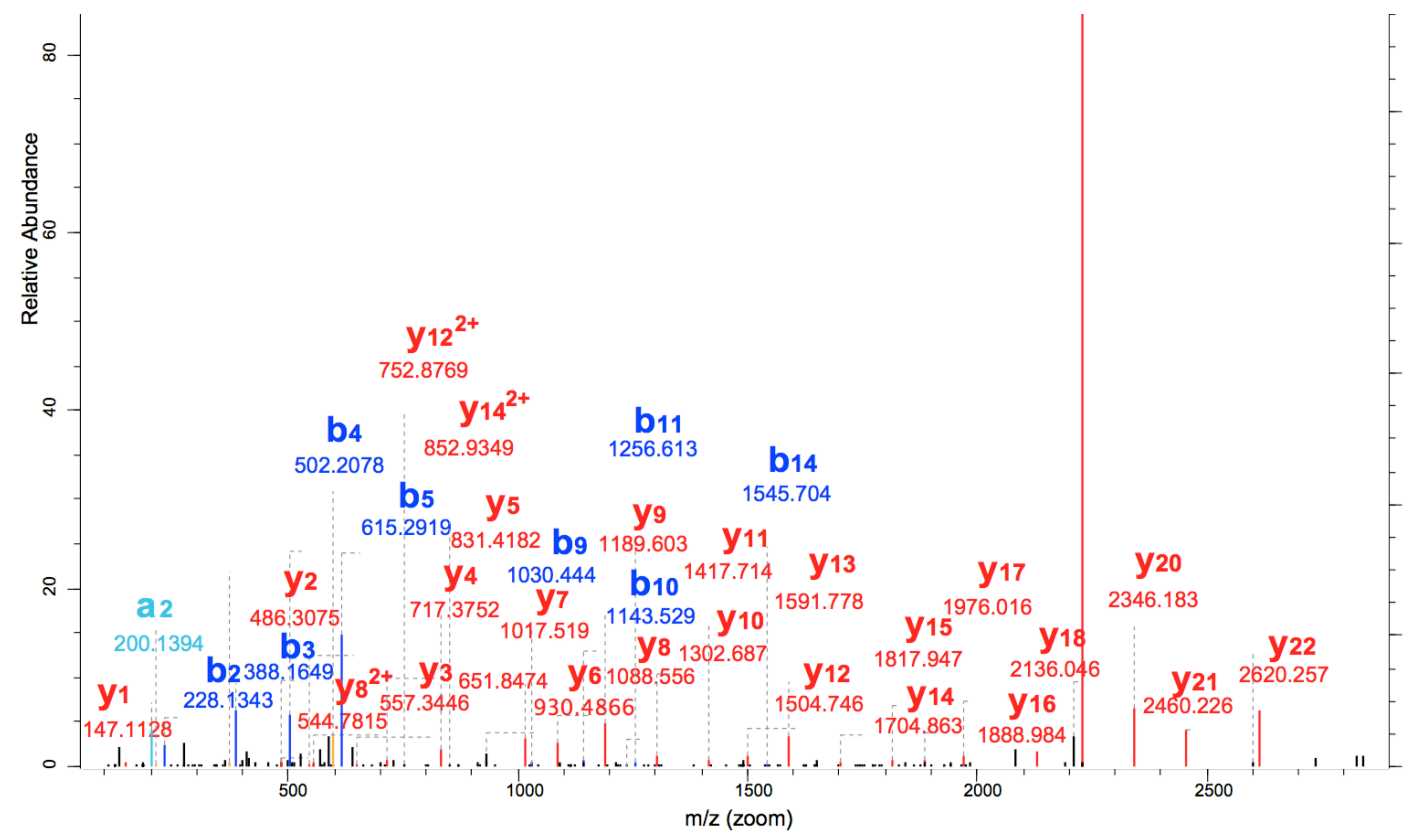

Figure S13. Covalent modification of lysine 114 by OPA-NH-alkyne. 


\subsection{Cultivation of bacteria and whole proteome labeling.}

Bacteria strain was streaked out onto an LB agar plate from a frozen stock. A single colony was inoculated in subsequent $100 \mathrm{~mL} \mathrm{LB}$ broth and maintained at $37^{\circ} \mathrm{C}$. After 12 hours, bacteria cells were harvested by centrifugation at $10,000 \mathrm{~g}$ for 10 minutes. The supernatant was discarded and cell pellets were collected.

Bacteria cell pellets were resuspended in PBS buffer with 1\% SDS and disrupted by sonication, and the resulting suspension was centrifuged at $13,000 \mathrm{~g}$ for $30 \mathrm{~min}$ at $4{ }^{\circ} \mathrm{C}$. The supernatant was collected and the protein concentration was determined by BCA assay. The cell lysates concentration was normalized to $2 \mathrm{mg} / \mathrm{mL}$ by PBS with $1 \%$ SDS for the following OPA-NH-alkyne labeling.

Bacteria cell lysates were prepared with the PBS buffer (pH 7.4) at the concentration of $2 \mathrm{mg} / \mathrm{mL}$. Then designated concentrations $(0.1 \mu \mathrm{M}, 0.5 \mu \mathrm{M}, 1 \mu \mathrm{M}, 5 \mu \mathrm{M}, 10 \mu \mathrm{M}$ and $20 \mu \mathrm{M})$ of OPA-NH-alkyne probe was added and incubated for designated time (5 min, $15 \mathrm{~min}, 30 \mathrm{~min}$ and $60 \mathrm{~min}$ ) at room temperature. After the incubation, hydrazine (100 eq.) was added to quench the labeling of OPA-NH-alkyne for 10 minutes. The final protein concentration was adjusted to 1.5 $\mathrm{mg} / \mathrm{mL}$ after the labeling and quenching for the following Click reaction by PBS with $1 \%$ SDS.

Incubation time: $30 \mathrm{~min}$

OPA-NH-alkyne/ $\mu \mathrm{M} \quad 0 \quad 0.10 .5151020$

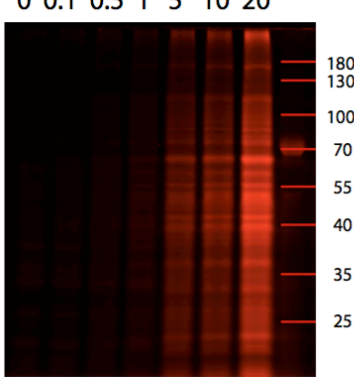

Coomassie Blue

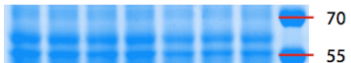

OPA-NH-alkyne: $10 \mu \mathrm{M}$

Incubation time/min $0 \quad 5153060$

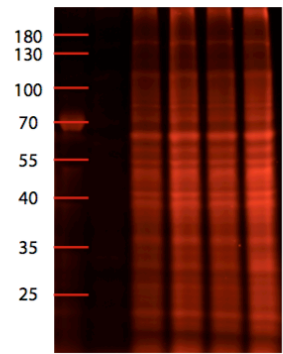

Coomassie Blue

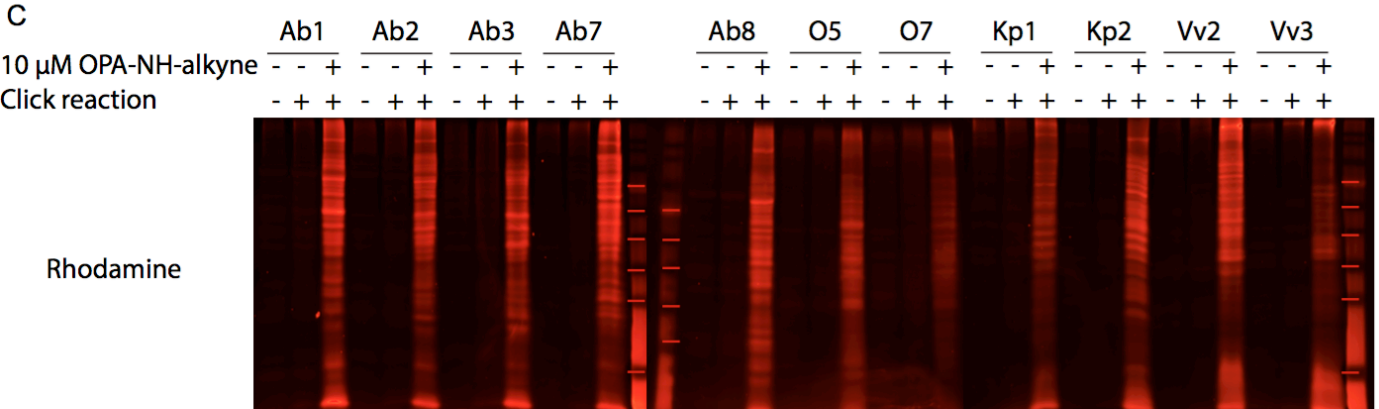


Figure S14. Proteome labeling of OPA-NH-alkyne biorthogonal handle in different gram-negative bacteria. A. Concentration-dependent labeling of OPA-NH-alkyne in PAO1 cell lysates $(2 \mathrm{mg} / \mathrm{mL})$ for 30 minutes; B. Time-dependent labeling of OPA-NH-alkyne $(10 \mu \mathrm{M})$ in PAO1 cell lysates $(2 \mathrm{mg} / \mathrm{mL})$; C. Labeling of OPA-NH-alkyne $(10 \mu \mathrm{M})$ in different bacteria cell lysates $(2 \mathrm{mg} / \mathrm{mL})$. Bacteria strains and abbreviations are shown in SI table 1.

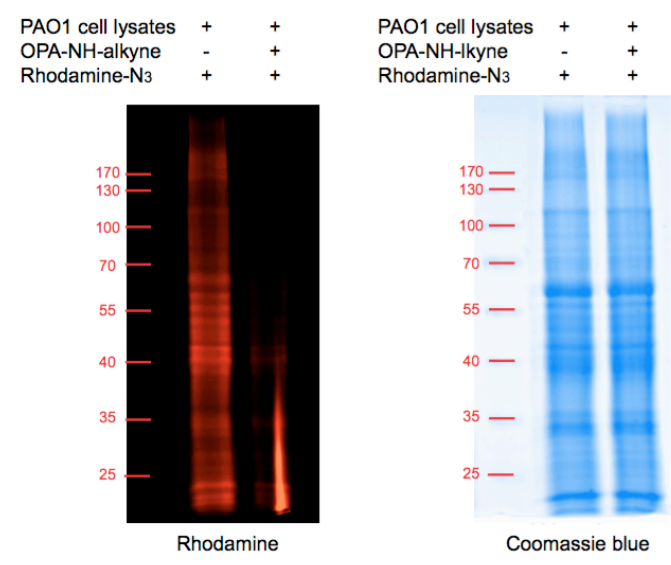

B

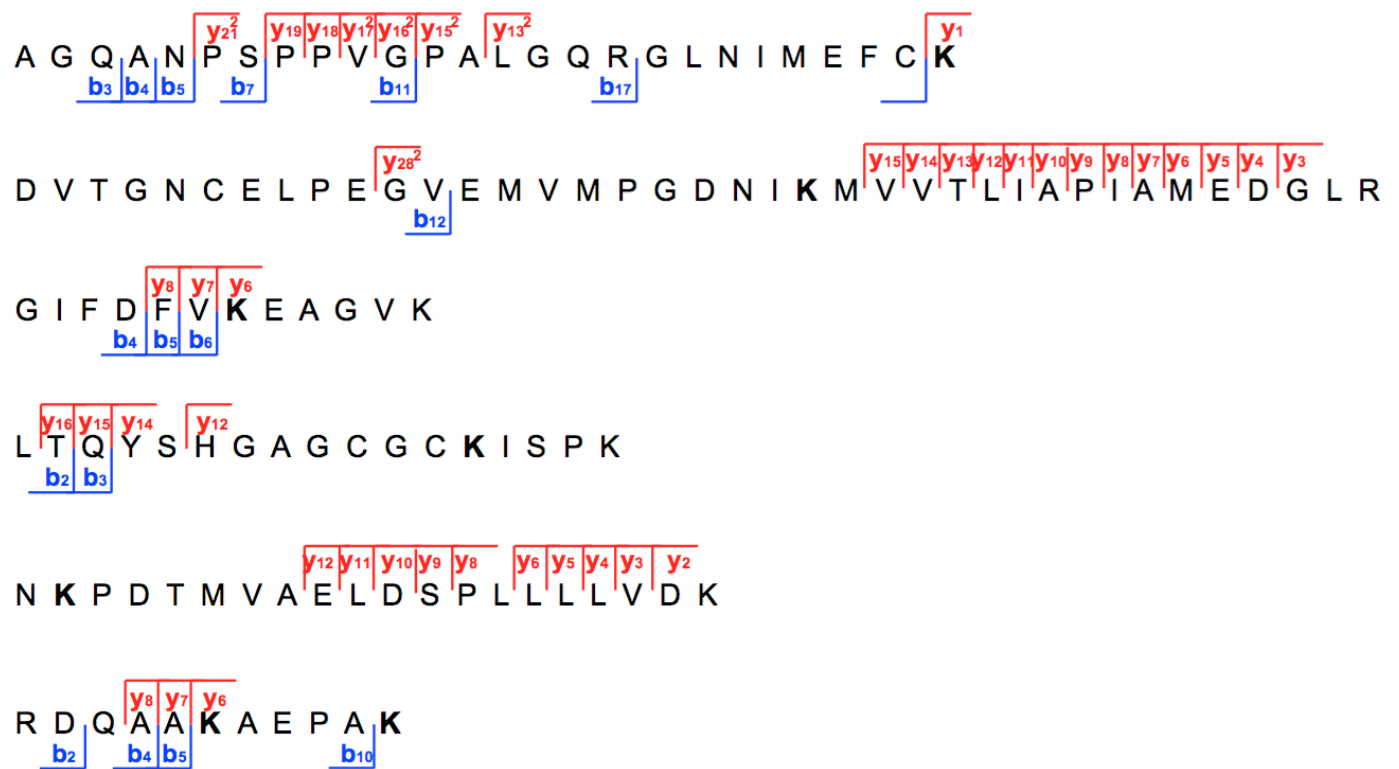

Figure S15. Proteome labeling of OPA-NH-alkyne biorthogonal handle in PAO1. A. SDS-page of OPA-NH-alkyne labeled PAO1 cell lysates after click with Rhodamine- $\mathrm{N}_{3}$; B. OPA-NH-alkyne labeled peptides from PAO1 cell lysates. 


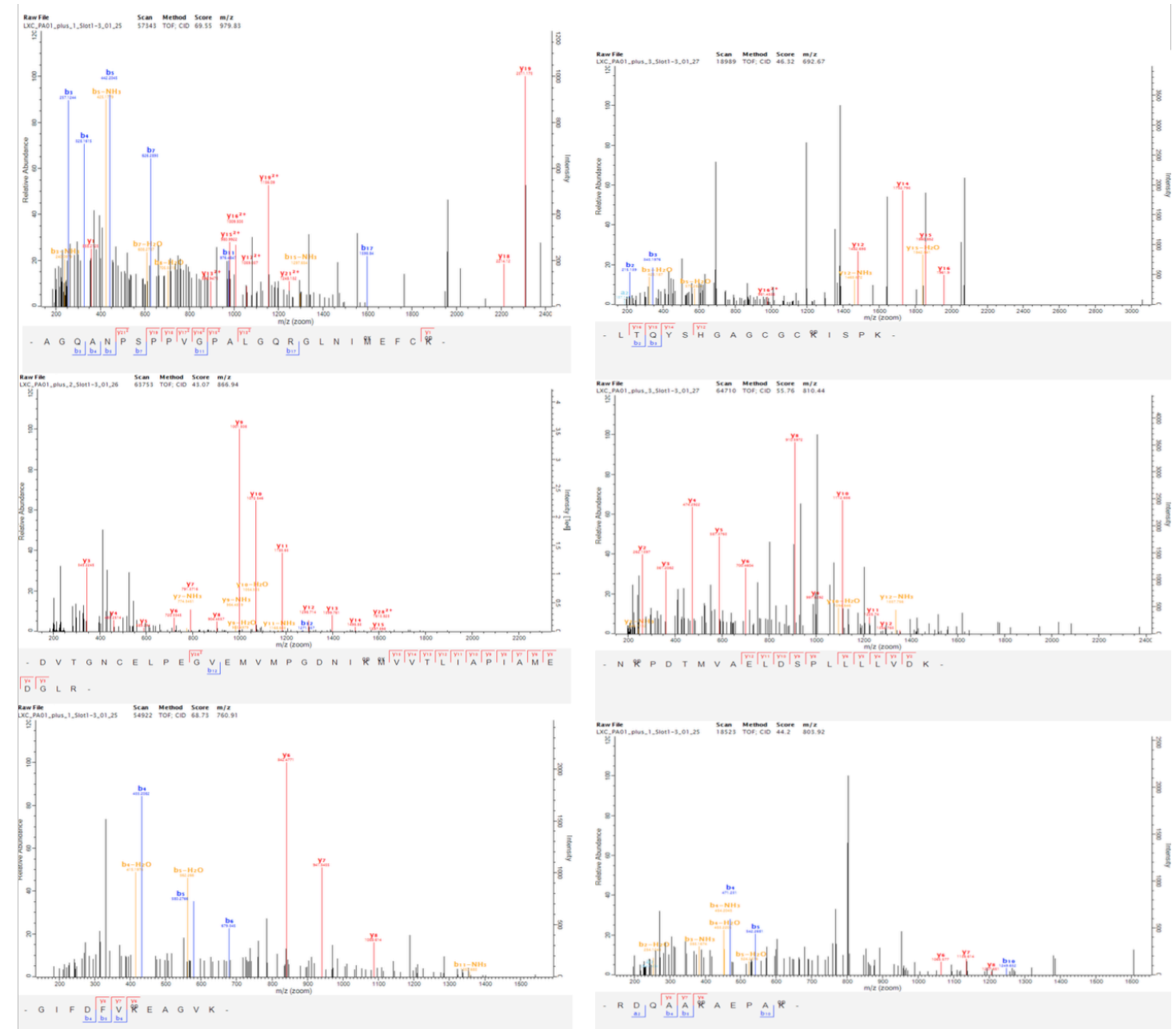

Figure S16. MS/MS spectrums of PAO1 cell lysates labeled by OPA-NH-alkyne. 


\subsection{Streptavidin affinity enrichment of biotinylated proteins}

$1 \mathrm{~mL}$ of PAO1 cell lysates $(2 \mathrm{mg} / \mathrm{mL})$ was treated with $10 \mu \mathrm{M}$ NHS-biotin or OPA-biotin separately at room temperature for 30 minutes and then $10 \mu \mathrm{L}$ of hydrazine was added to quench the reaction for 10 minutes. After the labeling by NHS-biotin and OPA-biotin, cell lysates were precipitated by $4 \mathrm{~mL}$ cold acetone at $-20{ }^{\circ} \mathrm{C}$ overnight. After washing with ice-cold methanol twice, the air-dried protein pellet was resuspended in $1 \mathrm{~mL} 6 \mathrm{M}$ urea, $25 \mathrm{mM} \mathrm{NH}_{4} \mathrm{HCO}_{3}$ and then diluted to $12 \mathrm{~mL}$ with PBS and enriched over streptavidin agarose $(100 \mu \mathrm{L} 50 \%$ slurry) for $2 \mathrm{~h}$ at room temperature. The streptavidin beads were washed with PBS with $0.2 \%$ SDS, $6 \mathrm{M}$ urea in PBS with $0.1 \%$ SDS and $250 \mathrm{mM} \mathrm{NH}_{4} \mathrm{HCO}_{3}$ with $0.05 \% \mathrm{SDS}$ in succession.
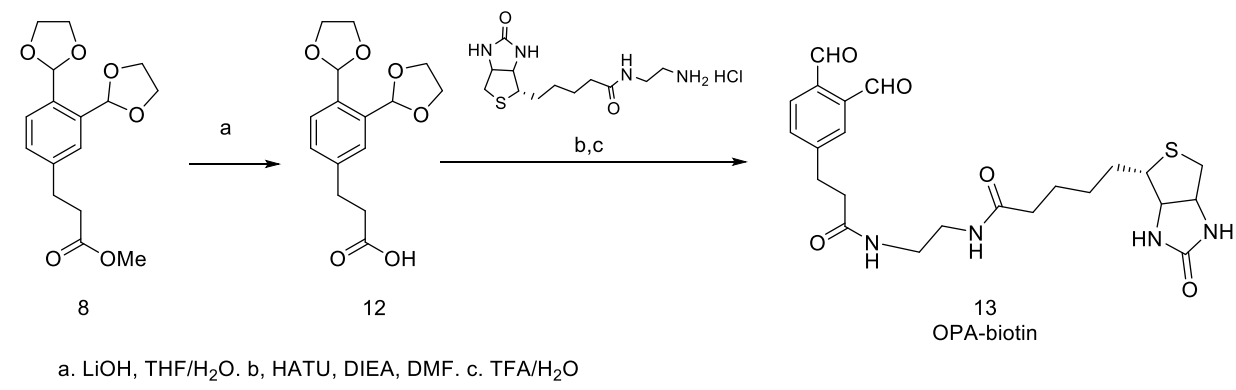

Scheme S1.6. Synthetic route of OPA-biotin

\subsection{MS sample preparation}

\section{On-beads digestion}

After the streptavidin enrichment, the streptavidin beads were washed twice with $1 \mathrm{~mL}$ of $50 \mathrm{mM}$ ammonium bicarbonate $(\mathrm{ABC})$. Subsequently, the samples were reduced with $5 \mathrm{mM}$ Tris (2-carboxyethyl) phosphine hydrochloride (TCEP) in $50 \mathrm{mM} \mathrm{ABC}$ at room temperature for 15 min and alkylated with $15 \mathrm{mM}$ iodoacetamide (IAA) in $50 \mathrm{mM} \mathrm{ABC}$ for $30 \mathrm{~min}$ at room temperature in dark. After an additional $5 \mathrm{mM}$ TCEP incubation for $15 \mathrm{~min}$, the beads were incubated with $1 \mu \mathrm{g}$ of trypsin (Promega) in $50 \mathrm{mM} \mathrm{ABC}$ overnight at $37{ }^{\circ} \mathrm{C}$. The digested peptides were collected by washing the beads with $1 \%(v / v)$ formic acid (FA), and the peptides were subjected to StageTip C18 desalting before MS analysis.

\section{In solution digestion}

$100 \mu \mathrm{g}$ lysozyme C was incubated with OPA-NH-alkyne (25 nmol) in $100 \mu \mathrm{L}$ PBS (pH 7.4) for 30 minutes at room temperature. $400 \mu \mathrm{L}$ ice-cold acetone was added to the mixture, which was placed at $-80^{\circ} \mathrm{C}$ for 2 hours to precipitate lysozyme C. After washing with ice-cold methanol twice, the air-dried protein pellet was dissolved in $100 \mu \mathrm{L}$ by $100 \mathrm{mM} \mathrm{NH}_{4} \mathrm{HCO}_{3}$ and then heated at $50{ }^{\circ} \mathrm{C}$ for $10 \mathrm{~min}$. Then $10 \mathrm{mM}$ dithiothreitol (DTT) was added and incubated at $56^{\circ} \mathrm{C}$ for $30 \mathrm{~min}$, followed by alkylation by $25 \mathrm{mM}$ iodoacetamide in the dark at room temperature for $30 \mathrm{~min}$. Proteins were digested with $0.2 \mu \mathrm{g}$ trypsin at $37^{\circ} \mathrm{C}$ for $16 \mathrm{~h}$. The resulting peptides were enriched with the StageTips. The eluted peptides from the StageTips were dried down by SpeedVac and then resuspended in $0.1 \%$ formic acid for analysis by LC/MS/MS. 


\subsection{MS analysis}

Peptides were resuspended in $10 \mu \mathrm{L} 0.1 \%(v / v)$ FA. The samples were analyzed with a Q-Exactive Orbitrap mass spectrometer (Thermo Fisher) directly coupled to an Easy-nLC 1000 nano HPLC system (Thermo Fisher). The nano HPLC separation system consisted of an analytical column with an integrated spray tip $(100 \mu \mathrm{m}$ inner diameter $\times 20 \mathrm{~cm})$ packed with $1.9 \mu \mathrm{m} / 120 \AA$ ReproSil-Pur C18 resin (Dr. Maisch GmbH). The buffers used for separation were 0.1\% (v/v) FA in water (buffer A) and $0.1 \%(v / v)$ FA in ACN (buffer B). Samples $(5 \mu \mathrm{L})$ were loaded onto the analytical column and separated at a flow rate of $250 \mathrm{~nL} / \mathrm{min}$. The gradient was set as follows: from 3 to $7 \%$ buffer B in $2 \mathrm{~min}$, from 7 to $22 \%$ buffer B in $100 \mathrm{~min}$, from $22 \%$ to $35 \%$ buffer B in $20 \mathrm{~min}$, from $35 \%$ to $90 \%$ buffer B in $2 \mathrm{~min}$, holding at $90 \%$ buffer B for $6 \mathrm{~min}$, declining to $3 \%$ buffer B in $2 \mathrm{~min}$, and holding at 3\% buffer B for $13 \mathrm{~min}$. For the MS scans, the full MS scan range was set to $350-1,550 \mathrm{~m} / \mathrm{z}$ with a mass resolution of 70,000 . The MS/MS spectra were acquired in data-dependent acquisition mode with the 10 most intense ions. Tandem MS was performed in the ion trap mass analyzer using an isolation window of 2.0 Da by quadrupole mass analyzer and high-energy collision-induced dissociation fragmentation with normalized collision energy of 27.

\subsection{Data analysis}

The raw data files were searched with MaxQuant software (version 1.5.5.1) (Cox J, Mann M (2008). MaxQuant enables high peptide identification rates, individualized p.p.b.-range mass accuracies and proteome-wide protein quantification against the pseudomonas aeruginosa UniProt FASTA database (downloaded on Nov. 21, 2018). ${ }^{[2]}$ The false discovery rate (FDR) evaluation was done by searching a reverse database and was set to 0.01 for proteins and peptides. All statistical and bioinformatics analyses were performed with the Perseus software (version 1.5.5.3, as part of the MaxQuant environment). The Perseus computational platform for comprehensive analysis of (prote)omics data, Microsoft Excel. ${ }^{[3]}$

The parameters were used as follow: cysteine carbamidomethylation was set as a fixed modification, whereas methionine oxidation, glutamine deamidation were set as variable modifications. The maximum number of missed cleavages was set to two for trypsin digestion. The "Match between runs" option was selected, and the other parameters were set to default values. Contaminants, proteins identified by reverse identification, proteins identified only by site and proteins with $\leq 1$ unique peptide were excluded from further analysis. Protein groups identified with " 3 " valid values "in at least one group" were reserved, and missing values were assigned an artificial value sampled from a normal distribution (width $=0.3$, down-shift $=1.8$ ). Proteins identified with an $\mathrm{FDR}=0.05$ and $\mathrm{s}_{0}=2$ were considered differentially regulated.

OPA-NH-alkyne was set as a variable modification with a mass shift of $+211.0997 \mathrm{Da}$, and the iodoacetamide derivative of cysteine was set as a fixed modification. The mass tolerance was 6 p.p.m. for peptide mass and $0.5 \mathrm{Da}$ for fragment ion mass. 
A

NHS-biotin

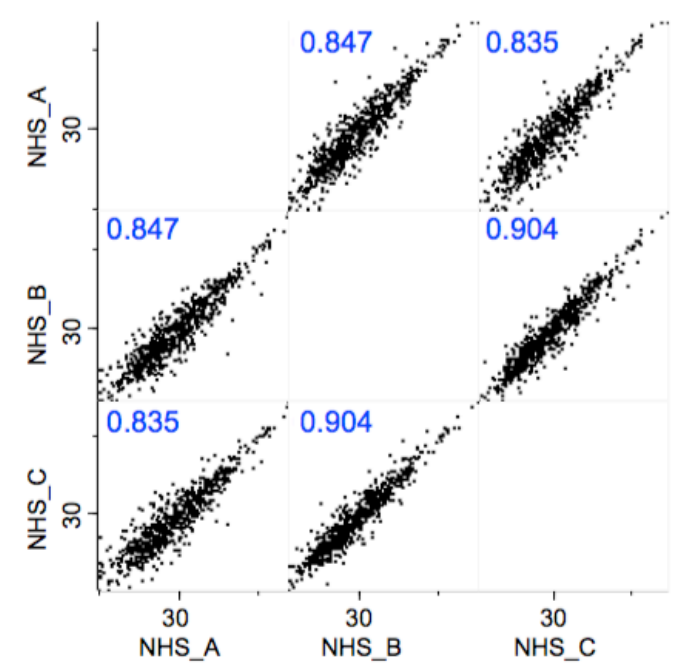

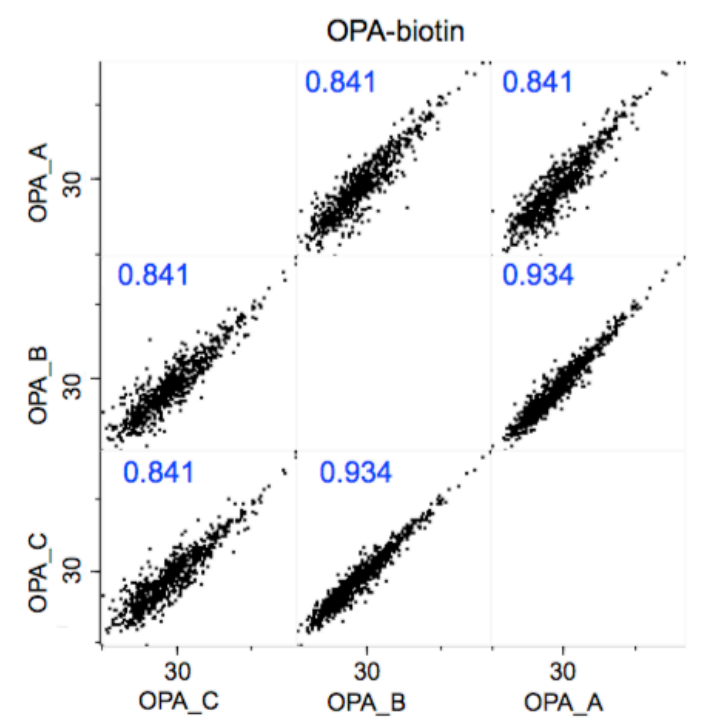

B

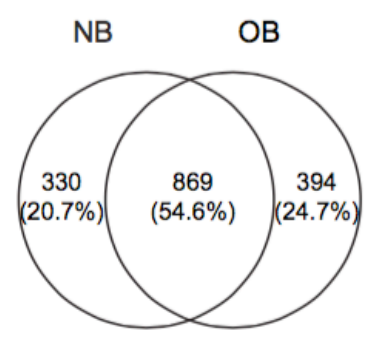

Sample A

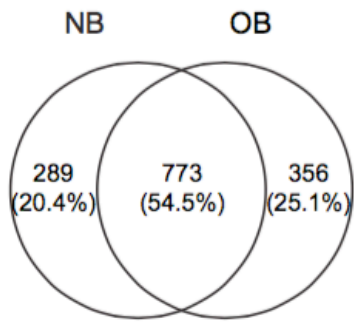

Sample B

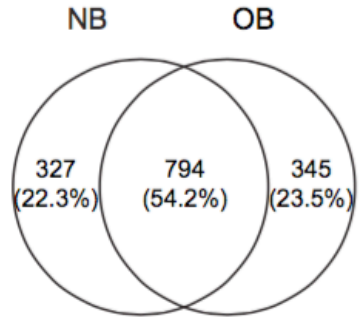

Sample C

\section{C}

Gene ontology analysis of the unique proteins labeled by NHS-biotin or OPA-biotin

\section{NHS specific proteins}

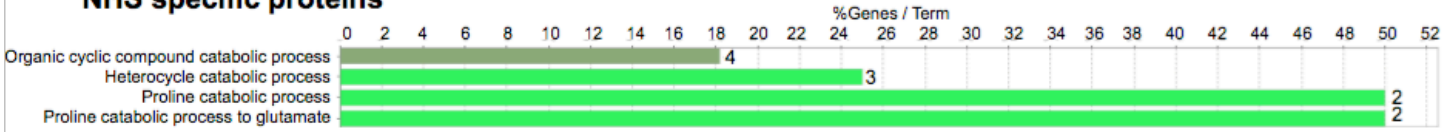

OPA specific proteins

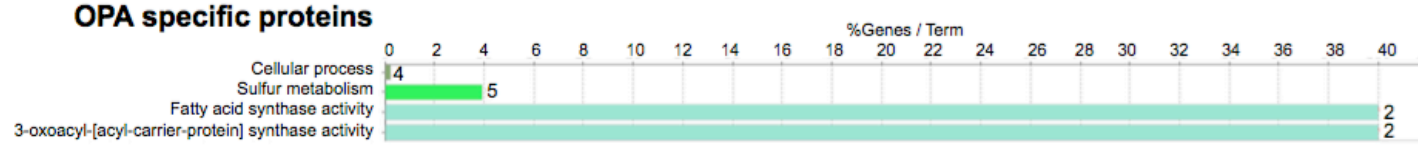

Figure S15. Comparison of the whole proteome profiling by NHS-biotin and OPA-biotin. A. MultiScatter of the three replicates of NHS-biotin and OPA-biotin separately. B. Comparison of labeled proteins by NHS-biotin and OPA-biotin for three replicates. C. Gene ontology analysis of the unique proteins labeled by NHS-biotin or OPA-biotin separately. 


\section{Synthesis part}

\subsection{Materials and Methods}

All commercial materials (Sigma-Aldrich, J\&K Scientific and GL Biochem) were used without further purification. All solvents were reagent grade or HPLC grade (RCI or DUKSAN). Anhydrous dichloromethane $\left(\mathrm{CH}_{2} \mathrm{Cl}_{2}\right)$ was distilled from calcium hydride $\left(\mathrm{CaH}_{2}\right)$. Analytical TLC was performed on Silica gel 60 F254 pre-coated glass plates. The normal phase column chromatography was performed on silica gel (230-400 mesh, Merck). ${ }^{1} \mathrm{H}$ and ${ }^{13} \mathrm{C}$ NMR spectra were recorded on Bruker Avance DRX 300 FT-NMR spectrometer at $300 \mathrm{MHz}$ for ${ }^{1} \mathrm{H}$ NMR and 75.47 MHz for ${ }^{13} \mathrm{C}$ NMR or Bruker Avance DRX 400 FT-NMR spectrometer at $400 \mathrm{MHz}$ for ${ }^{1} \mathrm{H}$ NMR and $100 \mathrm{MHz}$ for ${ }^{13} \mathrm{C}$ NMR. HPLC and MALDI-TOF MS methods were described specifically in the corresponding text below.

\subsection{General procedures for RP-LCMS detection}

For all the RP-LCMS detection of OPA-peptide conjugates, all separations involved a mobile phase of $0.1 \%$ TFA $(v / v)$ in acetonitrile and $0.1 \%$ TFA $(v / v)$ in water. HPLC separations were performed with Waters HPLC system equipped with photodiode array detector (Waters 2996) using Vydac $218 \mathrm{TP}$ C18 column $(5 \mu \mathrm{m}, 300 \AA, 4.6 \times 250 \mathrm{~mm})$ at a flow rate of $0.6 \mathrm{~mL} / \mathrm{min}$.

\subsection{Synthesis of OPA-alkyne bifunction linkers}

\subsubsection{Synthesis of methyl 3-(3,4-di(1,3-dioxolan-2-yl) phenyl) propanoate}

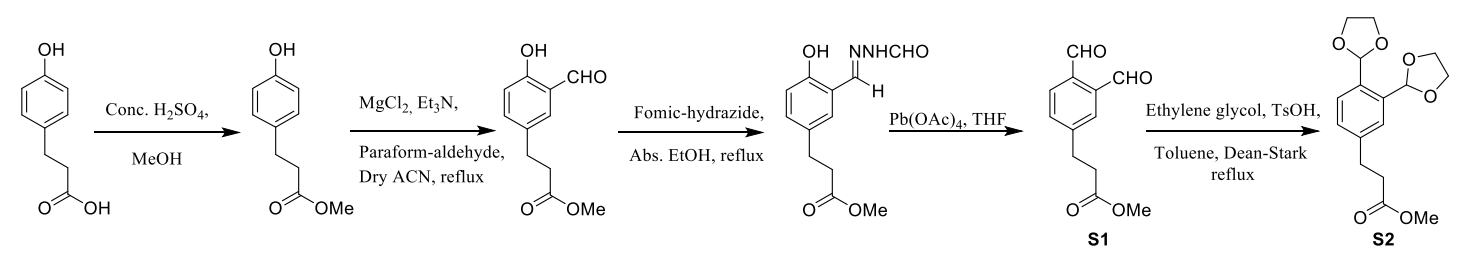

The compound $\mathbf{S 1}$ was prepared by following the reported procedures. ${ }^{[4]}$

Methyl 3-(3,4-di(1,3-dioxolan-2-yl)phenyl)propanoate (S2)

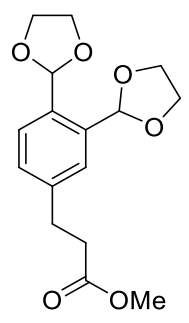

To a solution of compound S1 $(2.5 \mathrm{~g}, 9.22 \mathrm{mmol})$ in anhydrous toluene $(250 \mathrm{~mL})$, $p$-toluenesulfonic acid (32 mg, $0.185 \mathrm{mmol})$ and ethylene glycol $(5.2 \mathrm{~mL}, 92.15 \mathrm{mmol})$ were added. The mixture was refluxed in a dean-stark apparatus for $9 \mathrm{~h}$. After reaction was cooled down to room temperature, the reaction was quenched by $\mathrm{Et}_{3} \mathrm{~N}(0.8 \mathrm{~mL}, 5.7 \mathrm{mmol})$. The mixture was then evaporated under vacuo and the residue was dissolved in EtOAc. The organic layers were washed with sat. $\mathrm{NaHCO}_{3}$ (aq.) and brine, dried with anhydrous sodium sulfate and 
evaporated. The residue was purifiegd by flash column chromatography on silica gel (Hexane / EtOAc, $3: 1)$ to give compound $\mathbf{S 2}$ as yellow oil $(2.58 \mathrm{~g}, 90.5 \%) .{ }^{1} \mathrm{H} \mathrm{NMR}\left(300 \mathrm{MHz}, \mathrm{CDCl}_{3}\right) \delta=$ $7.55(\mathrm{~d}, \mathrm{~J}=7.9 \mathrm{~Hz}, 1 \mathrm{H}), 7.47$ (d, J = 1.9 Hz, 1H), 7.22 (dd, J = 8.0, $1.9 \mathrm{~Hz}, 1 \mathrm{H}), 6.19$ (s, 2H), 4.17 $-4.08(\mathrm{~m}, 4 \mathrm{H}), 4.08-3.99(\mathrm{~m}, 4 \mathrm{H}), 3.67$ (s, 3H), $2.96(\mathrm{dd}, \mathrm{J}=8.7,7.1 \mathrm{~Hz}, 2 \mathrm{H}), 2.62(\mathrm{dd}, \mathrm{J}=8.7$, $7.1 \mathrm{~Hz}, 2 \mathrm{H}) .{ }^{13} \mathrm{C}$ NMR $\left(300 \mathrm{MHz}, \mathrm{CD}_{3} \mathrm{CN}\right) \delta=141.48,136.08,134.10,128.96,126.41,125.92$, $100.69,100.65,65.29,65.27,51.62,35.52,30.74$. ESI-MS $(\mathrm{m} / \mathrm{z})$ : calcd for $\mathrm{C}_{16} \mathrm{H}_{20} \mathrm{O}_{6}[\mathrm{M}+\mathrm{H}]^{+}$: 309.13, found: 309.20 .

\subsubsection{Synthesis of 4-(3-(prop-2-yn-1-ylamino)propyl)phthalaldehyde hydrochloride}

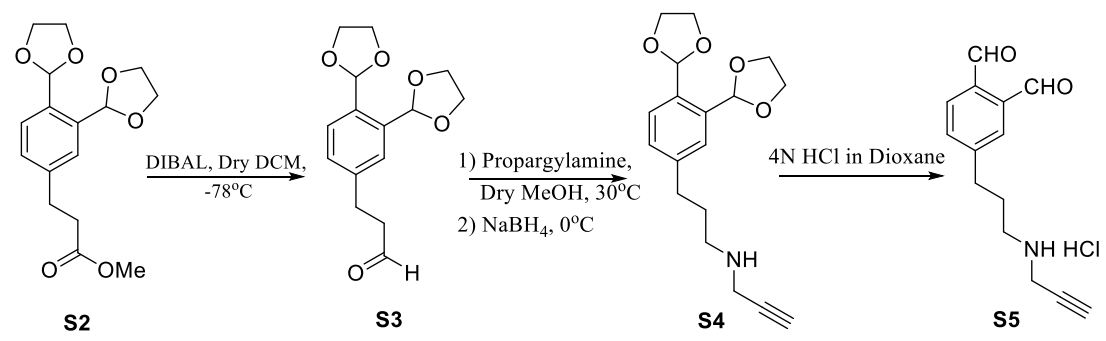

\section{3-(3,4-di(1,3-dioxolan-2-yl)phenyl)propanal (S3)}<smiles>O=CCCc1ccc(C2OCCO2)c(C2OCCO2)c1</smiles>

Under argon protection, to a solution of compound S2 $(469.5 \mathrm{mg}, 1.5 \mathrm{mmol})$ in anhydrous DCM $(30 \mathrm{~mL})$ at $-78^{\circ} \mathrm{C}$, DIBAL-H solution $(2 \mathrm{~mL}, 1 \mathrm{M}$ in Hex) was dropwise added. The mixture was stirred at $-78{ }^{\circ} \mathrm{C}$ for $2 \mathrm{~h}$. After reaction was completed, the reaction was slowly quenched by ice cold $\mathrm{MeOH}(0.8 \mathrm{~mL})$. The mixture was then warmed to room temperature, and followed by evaporating under vacuo and the residue was dissolved in EtOAc. The organic layers were washed with $1 \mathrm{~N} \mathrm{HCl}$ solution and brine, dried with anhydrous sodium sulfate and evaporated. The residue was purified by flash column chromatography on silica gel (Hexane / EtOAc, $2.5: 1$ ) to give compound $\mathbf{S 3}$ as light-yellow oil (304 mg, 70.2\%). ${ }^{1} \mathrm{H}$ NMR $\left(400 \mathrm{MHz}, \mathrm{CDCl}_{3}\right) \delta=9.80(\mathrm{~s}, 1 \mathrm{H})$, $7.56(\mathrm{~d}, \mathrm{~J}=7.9 \mathrm{~Hz}, 1 \mathrm{H}), 7.47(\mathrm{~d}, \mathrm{~J}=1.9 \mathrm{~Hz}, 1 \mathrm{H}), 7.21(\mathrm{dd}, \mathrm{J}=7.9,1.9 \mathrm{~Hz}, 1 \mathrm{H}), 4.19-4.08(\mathrm{~m}$, $4 \mathrm{H}), 4.08-3.96(\mathrm{~m}, 4 \mathrm{H}), 2.96(\mathrm{t}, \mathrm{J}=7.6 \mathrm{~Hz}, 2 \mathrm{H}), 2.77(\mathrm{td}, \mathrm{J}=7.4,6.9,1.3 \mathrm{~Hz}, 2 \mathrm{H}) .{ }^{13} \mathrm{C} \mathrm{NMR}$ $\left(400 \mathrm{MHz}, \mathrm{CDCl}_{3}\right) \delta=201.29,141.33,136.17,134.18,128.95,126.48,125.87,100.64,65.27$, 65.25, 45.10, 27.88. ESI-MS (m/z): calcd for $\mathrm{C}_{15} \mathrm{H}_{18} \mathrm{O}_{5}[\mathrm{M}+\mathrm{H}]^{+}: 279.12$, found: 279.19 . 


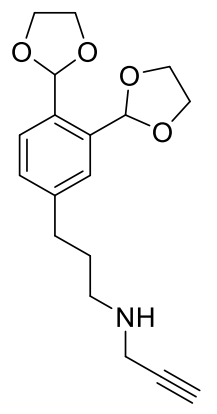

To a $25 \mathrm{~mL}$ round bottom flask, anhydrous $\mathrm{MgSO}_{4}$ was added, followed by $\mathbf{S 3}$ (177 $\mathrm{mg}, 0.63$ $\mathrm{mmol})$ in anhydrous $\mathrm{MeOH}(5 \mathrm{~mL})$. Under argon protection the reaction mixture was sonicated, followed by adding propargylamine $(164 \mu \mathrm{L}, 2.52 \mathrm{mmol})$, and the reaction was stirred at room temperature for $15 \mathrm{~h}$. To this solution, $\mathrm{NaBH}_{4}(49 \mathrm{mg}, 1.26 \mathrm{mmol})$ was added at $0{ }^{\circ} \mathrm{C}$, then the mixture was stirred at $0{ }^{\circ} \mathrm{C}$ for $30 \mathrm{~min}$ and warmed to the room temperature, followed by evaporating under vacuo and the residue was dissolved in EtOAc. The organic layers were washed with sat. $\mathrm{NH}_{4} \mathrm{Cl}$ (aq.) and brine, dried with anhydrous sodium sulfate and evaporated. The residue was purified by flash column chromatography on silica gel (Hexane / EtOAc, $1: 4$ ) to give compound $\mathbf{S 4}$ as yellow oil (79 mg, 46\%). ${ }^{1} \mathrm{H}$ NMR $\left(400 \mathrm{MHz}, \mathrm{CDCl}_{3}\right) \delta=7.54(\mathrm{~d}, \mathrm{~J}=7.9 \mathrm{~Hz}$, $1 \mathrm{H}), 7.46(\mathrm{~d}, \mathrm{~J}=1.9 \mathrm{~Hz}, 1 \mathrm{H}), 7.21(\mathrm{dd}, \mathrm{J}=7.9,1.9 \mathrm{~Hz}, 1 \mathrm{H}), 6.19(\mathrm{~s}, 2 \mathrm{H}), 4.12(\mathrm{~m}, 4 \mathrm{H}), 4.05-$ $3.99(\mathrm{~m}, 4 \mathrm{H}), 3.41(\mathrm{~d}, \mathrm{~J}=2.4 \mathrm{~Hz}, 2 \mathrm{H}), 2.70(\mathrm{dt}, \mathrm{J}=10.5,7.7 \mathrm{~Hz}, 4 \mathrm{H}), 2.20(\mathrm{t}, \mathrm{J}=2.4 \mathrm{~Hz}, 1 \mathrm{H})$, $1.81(\mathrm{dq}, \mathrm{J}=9.7,7.3 \mathrm{~Hz}, 2 \mathrm{H}) .{ }^{13} \mathrm{C} \mathrm{NMR}\left(400 \mathrm{MHz}, \mathrm{CDCl}_{3}\right) \delta=143.02,135.84,133.58,129.01$, $126.22,125.98,100.76,82.22,71.23,65.25,65.23,48.09,38.09,33.33,31.26,29.65$. HR-ESI-MS $(\mathrm{m} / \mathrm{z})$ : calcd for $\mathrm{C}_{18} \mathrm{H}_{23} \mathrm{~N}_{1} \mathrm{O}_{4}[\mathrm{M}+\mathrm{H}]^{+}: 318.1700$, found: 318.2175 .

4-(3-(prop-2-yn-1-ylamino)propyl)phthalaldehyde hydrochloride (S5)<smiles>C#CCNCCCc1ccc(C=O)c(C=O)c1</smiles>

To a solution of compound $\mathbf{S 4}(52 \mathrm{mg}, 0.164 \mathrm{mmol})$ in DCM $(2 \mathrm{~mL})$, the $4 \mathrm{~N} \mathrm{HCl}$ in dioxane $(8$ $\mathrm{mL}$ ) was slowly added, and the mixture was stirred at room temperature for $3 \mathrm{~h}$. After the reaction was completed, the mixture was evaporated under vacuo and the residue was dissolved in EtOAc $(200 \mathrm{~mL})$. The organic layers were washed with sat. $\mathrm{NaHCO}_{3}$ (aq.) and brine $(10 \mathrm{~mL})$, dried with anhydrous sodium sulfate and evaporated. The residue was purified by flash column chromatography on silica gel (EtOAc, to $\mathrm{DCM} / \mathrm{MeOH}, 15: 1$ ) to give compound $\mathbf{S 5}$ as yellow solid (30 mg, 68.6\%). ${ }^{1} \mathrm{H}$ NMR $\left(500 \mathrm{MHz}, \mathrm{CDCl}_{3}\right) \delta=10.52(\mathrm{~s}, 1 \mathrm{H}), 10.44(\mathrm{~s}, 1 \mathrm{H}), 7.89(\mathrm{~d}, \mathrm{~J}=$ $7.7 \mathrm{~Hz}, 1 \mathrm{H}), 7.76(\mathrm{~d}, \mathrm{~J}=1.8 \mathrm{~Hz}, 1 \mathrm{H}), 7.57(\mathrm{dd}, \mathrm{J}=7.8,1.8 \mathrm{~Hz}, 1 \mathrm{H}), 3.78(\mathrm{~d}, \mathrm{~J}=2.6 \mathrm{~Hz}, 2 \mathrm{H}), 3.13$ $(\mathrm{t}, \mathrm{J}=7.8 \mathrm{~Hz}, 2 \mathrm{H}), 2.87(\mathrm{t}, \mathrm{J}=7.8 \mathrm{~Hz}, 2 \mathrm{H}), 2.51(\mathrm{t}, \mathrm{J}=2.6 \mathrm{~Hz}, 1 \mathrm{H}), 2.13(\mathrm{t}, \mathrm{J}=7.7 \mathrm{~Hz}, 2 \mathrm{H}) .{ }^{13} \mathrm{C}$ NMR $\left(500 \mathrm{MHz}, \mathrm{CDCl}_{3}\right) \delta=192.26,191.89,146.53,136.74,134.84,133.45,132.07,130.45$, 77.70, 72.81, 45.75, 36.35, 32.39, 26.82. HR-ESI-MS (m/z): calcd for $\mathrm{C}_{14} \mathrm{H}_{15} \mathrm{~N}_{1} \mathrm{O}_{2}[\mathrm{M}+\mathrm{H}]^{+}$: 
230.1176, found: 230.1175 .

\subsubsection{Synthesis of 4-(3-(prop-2-yn-1-yloxy)propyl)phthalaldehyde}

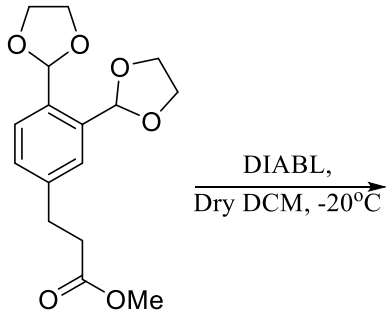

S2

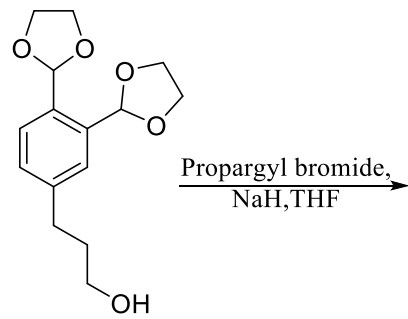

S6

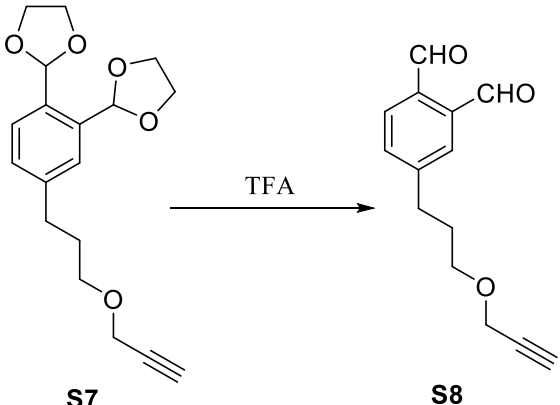

S7
S8

\section{3-(3,4-di(1,3-dioxolan-2-yl)phenyl)propan-1-ol (S6)}<smiles>OCCCc1ccc(C2OCCO2)c(C2OCCO2)c1</smiles>

Under argon protection, to a solution of compound $\mathbf{S 2}(350 \mathrm{mg}, 1.13 \mathrm{mmol})$ in anhydrous DCM $(25 \mathrm{~mL})$ at $-20^{\circ} \mathrm{C}$, DIBAL-H solution $(3.5 \mathrm{~mL}, 1 \mathrm{M}$ in Hex) was dropwise added. The mixture was stirred at $-20^{\circ} \mathrm{C}$ for $3 \mathrm{~h}$. After reaction was completed, the reaction was quenched by cold $\mathrm{MeOH}$ $(1 \mathrm{~mL})$. The mixture was then warmed to room temperature, and followed by evaporating under vacuo and the residue was dissolved in EtOAc. The organic layers were washed with $1 \mathrm{~N} \mathrm{HCl}$ solution and brine, dried with anhydrous sodium sulfate and evaporated. The residue was purified by flash column chromatography on silica gel (Hexane / EtOAc, $1: 1$ ) to give compound $\mathbf{S 6}$ as colorless oil (250 mg, 79\%). ${ }^{1} \mathrm{H}$ NMR $\left(400 \mathrm{MHz}, \mathrm{CDCl}_{3}\right) \delta=7.54(\mathrm{~d}, \mathrm{~J}=7.9 \mathrm{~Hz}, 1 \mathrm{H}), 7.46(\mathrm{~d}, \mathrm{~J}=$ $1.9 \mathrm{~Hz}, 1 \mathrm{H}), 7.21(\mathrm{dd}, \mathrm{J}=7.9,1.9 \mathrm{~Hz}, 1 \mathrm{H}), 6.18(\mathrm{~s}, 2 \mathrm{H}), 4.14-4.11(\mathrm{~m}, 4 \mathrm{H}), 4.08-3.98(\mathrm{~m}, 4 \mathrm{H})$, $3.63(\mathrm{t}, \mathrm{J}=6.5 \mathrm{~Hz}, 2 \mathrm{H}), 2.70(\mathrm{t}, \mathrm{J}=8.8,6.7 \mathrm{~Hz}, 2 \mathrm{H}), 1.90-1.82(\mathrm{~m}, 2 \mathrm{H}) .{ }^{13} \mathrm{C}$ NMR $(400 \mathrm{MHz}$, $\left.\mathrm{CDCl}_{3}\right) \delta=142.817,135.805,133.568,129.038,126.227,125.987,100.693,65.195,62.031$, 33.942, 31.777, 29.599. ESI-MS (m/z): calcd for $\mathrm{C}_{15} \mathrm{H}_{20} \mathrm{O}_{5}[\mathrm{M}+\mathrm{H}]^{+}: 281.14$, found: 281.20 .

\section{2,2'-(4-(3-(prop-2-yn-1-yloxy)propyl)-1,2-phenylene)bis(1,3-dioxolane) (S7)}<smiles>C#CCOCCCc1ccc(C2OCCO2)c(C2OCCO2)c1</smiles>

To a solution of compound $\mathbf{S 6}(50 \mathrm{mg}, 0.178 \mathrm{mmol})$ in anhydrous THF $(8 \mathrm{~mL})$ at $0{ }^{\circ} \mathrm{C}$, sodium 
hydride ( $60 \%$ dispersion in mineral oil) $(9 \mathrm{mg}, 0.220 \mathrm{~mol})$ was slowly added. The mixture was stirred at $0{ }^{\circ} \mathrm{C}$ for $30 \mathrm{~min}$, then propargyl bromide $(100 \mu \mathrm{L}, 0.536 \mathrm{mmol})$ was dropwise added into the reaction. The mixture was warmed to the room temperature and stirred for overnight. After the reaction was completed, the mixture was evaporated under vacuo and the residue was dissolved in EtOAc. The organic layers were washed with $1 \mathrm{~N} \mathrm{HCl} \mathrm{(aq.)} \mathrm{and} \mathrm{brine,} \mathrm{dried} \mathrm{with} \mathrm{anhydrous}$ sodium sulfate and evaporated. The residue was purified by flash column chromatography on silica gel (Hexane / EtOAc, $2: 1$ ) to give compound $\mathbf{S} 7$ as yellow solid (12 mg, 22.1\%). ${ }^{1} \mathrm{H}$ NMR $\left(400 \mathrm{MHz}, \mathrm{CDCl}_{3}\right) \delta=7.54(\mathrm{~d}, \mathrm{~J}=7.9 \mathrm{~Hz}, 1 \mathrm{H}), 7.47(\mathrm{~d}, \mathrm{~J}=1.9 \mathrm{~Hz}, 1 \mathrm{H}), 7.21(\mathrm{dd}, \mathrm{J}=7.9,1.9 \mathrm{~Hz}$, $1 \mathrm{H}), 6.19(\mathrm{~s}, 2 \mathrm{H}), 4.15-4.11(\mathrm{~m}, 6 \mathrm{H}), 4.05-4.01(\mathrm{~m}, 4 \mathrm{H}), 3.51(\mathrm{td}, \mathrm{J}=6.3,0.9 \mathrm{~Hz}, 2 \mathrm{H}), 2.76-$ $2.68(\mathrm{~m}, 2 \mathrm{H}), 2.42(\mathrm{~d}, \mathrm{~J}=0.9 \mathrm{~Hz}, 1 \mathrm{H}), 1.97-1.86(\mathrm{~m}, 2 \mathrm{H}) .{ }^{13} \mathrm{C} \mathrm{NMR}\left(400 \mathrm{MHz}, \mathrm{CDCl}_{3}\right) \delta=$ 142.739, 135.804, 133.547, 129.093, 126.171, 126.084, 100.714, 80.010, 74.136, 69.136, 65.200, 57.995, 32.005, 30.678. HR-ESI-MS (m/z): calcd for $\mathrm{C}_{18} \mathrm{H}_{22} \mathrm{O}_{5}[\mathrm{M}+\mathrm{H}]^{+}: 319.1540$, found:3 19.1049.

\section{4-(3-(prop-2-yn-1-yloxy)propyl)phthalaldehyde (S8)}<smiles>C#CCOCCCc1ccc(C=O)c(C=O)c1</smiles>

To a $25 \mathrm{~mL}$ round bottom flask, compound $\mathbf{S} 7(95 \mathrm{mg}, 0.298 \mathrm{mmol})$ was added, followed by slowly adding TFA $(8 \mathrm{~mL})$. The reaction was stirred at room temperature for $4 \mathrm{~h}$. The mixture was then evaporated under vacuo, and the residue was purified by flash column chromatography on silica gel (DCM / EtOAc, $3: 1)$ to give compound $\mathbf{S 8}$ as light-yellow solid (50 mg, $72 \%$ ). ${ }^{1} \mathrm{H}$ NMR $\left(400 \mathrm{MHz}, \mathrm{CDCl}_{3}\right) \delta=10.52(\mathrm{~s}, 1 \mathrm{H}), 10.45(\mathrm{~s}, 1 \mathrm{H}), 7.88(\mathrm{~d}, \mathrm{~J}=7.8 \mathrm{~Hz}, 1 \mathrm{H}), 7.78(\mathrm{~d}, \mathrm{~J}=1.8$ $\mathrm{Hz}, 1 \mathrm{H}), 7.58(\mathrm{dd}, \mathrm{J}=7.8,1.8 \mathrm{~Hz}, 1 \mathrm{H}), 4.13(\mathrm{~d}, \mathrm{~J}=2.4 \mathrm{~Hz}, 2 \mathrm{H}), 3.51(\mathrm{t}, \mathrm{J}=6.1 \mathrm{~Hz}, 2 \mathrm{H}), 2.85(\mathrm{dd}$, $\mathrm{J}=8.6,6.7 \mathrm{~Hz}, 2 \mathrm{H}), 2.42(\mathrm{t}, \mathrm{J}=2.4 \mathrm{~Hz}, 1 \mathrm{H}), 2.00-1.89(\mathrm{~m}, 2 \mathrm{H}) .{ }^{13} \mathrm{C} \mathrm{NMR}\left(400 \mathrm{MHz}, \mathrm{CDCl}_{3}\right)$ $\delta=192.460,191.978,148.850,136.476,134.310,133.713,131.645,130.942,79.668,74.393$, 68.465, 58.069, 32.191, 30.466. HR-ESI-MS (m/z): calcd for $\mathrm{C}_{14} \mathrm{H}_{14} \mathrm{O}_{3}[\mathrm{M}+\mathrm{H}]^{+}: 231.1016$, found: 231.1013 . 


\subsubsection{Synthesis of 4-(but-3-yn-1-yl) phthalaldehyde}

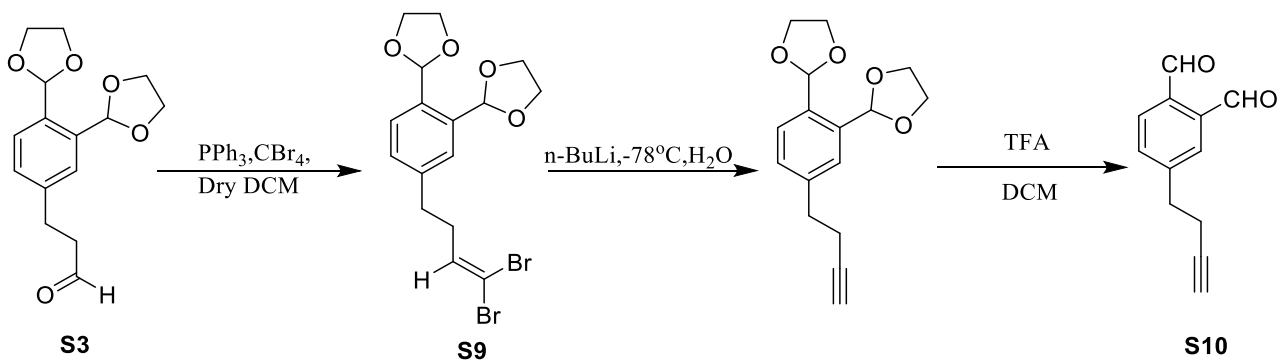

\section{2,2'-(4-(4,4-dibromobut-3-en-1-yl)-1,2-phenylene)bis(1,3-dioxolane) (S9)}<smiles>BrC(Br)=CCCc1ccc(C2OCCO2)c(C2OCCO2)c1</smiles>

To a solution of triphenylphosphine $(262 \mathrm{mg}, 1 \mathrm{mmol})$ in anhydrous DCM $(20 \mathrm{~mL})$ at $0{ }^{\circ} \mathrm{C}$, the solution of tetrabromomethane $(79.5 \mathrm{mg}, 0.5 \mathrm{mmol})$ in $20 \mathrm{~mL}$ anhydrous DCM was dropwise added. After the reaction was stirred at $0{ }^{\circ} \mathrm{C}$ for $15 \mathrm{~min}$, compound $\mathbf{S 3}(70 \mathrm{mg}, 0.251 \mathrm{mmol})$ in anhydrous DCM was dropwise added in the reaction mixture. The reaction was monitored by TLC plate. After the reaction was completed, the reaction was quenched by sat. $\mathrm{NaHCO}_{3}$ (aq.) and extracted by DCM. The organic layers were washed with brine, dried with anhydrous sodium sulfate and evaporated. The residue was purified by flash column chromatography on silica gel (Hexane / EtOAc, $5: 1$ ) to give compound $\mathbf{S 9}$ as white solid (18 mg, 16.1\%). ${ }^{1} \mathrm{H}$ NMR (500 MHz, $\left.\mathrm{CDCl}_{3}\right) \delta=7.57(\mathrm{~d}, \mathrm{~J}=7.9 \mathrm{~Hz}, 1 \mathrm{H}), 7.46(\mathrm{~d}, \mathrm{~J}=1.9 \mathrm{~Hz}, 1 \mathrm{H}), 7.20(\mathrm{dd}, \mathrm{J}=8.0,2.0 \mathrm{~Hz}, 1 \mathrm{H}), 6.40(\mathrm{t}$, $\mathrm{J}=7.2 \mathrm{~Hz}, 1 \mathrm{H}), 6.21(\mathrm{~d}, \mathrm{~J}=2.4 \mathrm{~Hz}, 2 \mathrm{H}), 4.17-4.10(\mathrm{~m}, 4 \mathrm{H}), 4.07-4.01(\mathrm{~m}, 4 \mathrm{H}), 2.75(\mathrm{t}, \mathrm{J}=7.7$ $\mathrm{Hz}, 2 \mathrm{H}), 2.44-2.38(\mathrm{~m}, 2 \mathrm{H}) .{ }^{13} \mathrm{C}$ NMR $\left(500 \mathrm{MHz}, \mathrm{CDCl}_{3}\right) \delta=141.47,137.48,136.16,134.15$, 128.97, 126.44, 125.97, 100.73, 100.71, 89.56, 65.29, 65.27, 34.34, 33.61. ESI-MS (m/z): calcd for $\mathrm{C}_{16} \mathrm{H}_{18} \mathrm{Br}_{2} \mathrm{O}_{4}[\mathrm{M}+\mathrm{H}]^{+}:$432.96, found: 433.12 .

\section{4-(but-3-yn-1-yl)phthalaldehyde (S10)}<smiles>C#CCCc1ccc(C=O)c(C=O)c1</smiles>

Under argon protection, a solution of compound $\mathbf{S 9}(45 \mathrm{mg}, 0.104 \mathrm{mmol})$ in anhydrous DCM (30 $\mathrm{mL}$ ) was cooled to $-78^{\circ} \mathrm{C}$, and then $n$-BuLi solution $(0.2 \mathrm{~mL}, 1.6 \mathrm{M}$ in THF) was dropwise added. 
The mixture was stirred at $-78{ }^{\circ} \mathrm{C}$ for $2 \mathrm{~h}$. Then $0.5 \mathrm{~N} \mathrm{HCl}$ (aq.) and DCM $(100 \mathrm{~mL})$ were added into the reaction, the reaction was allowed to warm to the room temperature and stirred for $15 \mathrm{~min}$. The organic layers were washed with brine, dried with anhydrous sodium sulfate and evaporated. The crude residue was treated with TFA/DCM $(3: 1,8 \mathrm{~mL})$, and the mixture was stirred at room temperature for $3 \mathrm{~h}$. After the reaction was completed, the mixture was concentrated and purified by flash column chromatography on silica gel (Hexane / EtOAc, $5: 1$ ) to give compound S10 as light yellow solid (10 mg, 40.5\%). ${ }^{1} \mathrm{H}$ NMR $\left(400 \mathrm{MHz}, \mathrm{CDCl}_{3}\right) \delta=10.57(\mathrm{~s}, 1 \mathrm{H}), 10.49(\mathrm{~s}, 1 \mathrm{H})$, $7.93(\mathrm{~d}, \mathrm{~J}=7.8 \mathrm{~Hz}, 1 \mathrm{H}), 7.85(\mathrm{~d}, \mathrm{~J}=1.8 \mathrm{~Hz}, 1 \mathrm{H}), 7.65(\mathrm{dd}, \mathrm{J}=7.8,1.8 \mathrm{~Hz}, 1 \mathrm{H}), 2.99(\mathrm{t}, \mathrm{J}=7.1 \mathrm{~Hz}$, $2 \mathrm{H}), 2.57(\mathrm{td}, \mathrm{J}=7.2,2.6 \mathrm{~Hz}, 2 \mathrm{H}), 1.99(\mathrm{t}, \mathrm{J}=2.6 \mathrm{~Hz}, 1 \mathrm{H}) .{ }^{13} \mathrm{C} \mathrm{NMR}\left(500 \mathrm{MHz}, \mathrm{CDCl}_{3}\right) \delta=$ 192.34, 191.99, 147.01, 136.54, 133.81, 131.73, 130.98, 70.05, 34.43, 29.68, 19.84. HR-ESI-MS $(\mathrm{m} / \mathrm{z})$ : calcd for $\mathrm{C}_{12} \mathrm{H}_{10} \mathrm{O}_{2}[\mathrm{M}+\mathrm{H}]^{+}: 187.0754$, found: 187.0071 .

\subsubsection{Synthesis of OPA-biotin linker}

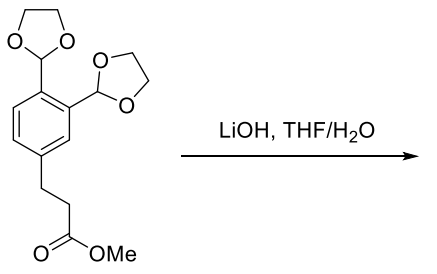

S2

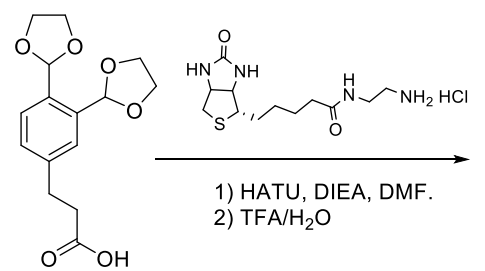

S11

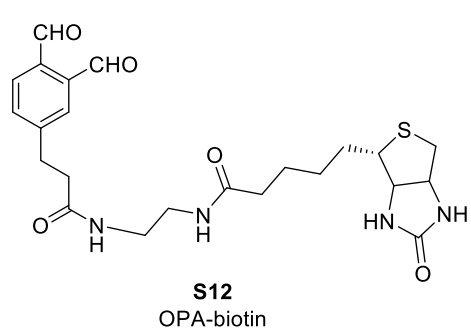

\section{3-(3,4-di(1,3-dioxolan-2-yl)phenyl)propanoic acid (S11)}<smiles>O=C(O)CCc1ccc(C2OCCO2)c(C2OCCO2)c1</smiles>

To a solution of compound $\mathbf{S 2}(2.5 \mathrm{~g}, 8.1 \mathrm{mmol})$ in $\mathrm{THF} / \mathrm{H}_{2} \mathrm{O}(3: 1, v / v)$ at room temperature, the solution of $\mathrm{LiOH}\left(583 \mathrm{mg}, 24.3 \mathrm{mmol}\right.$ ) in $\mathrm{H}_{2} \mathrm{O}$ was slowly added. The mixture was stirred at room temperature for overnight. Then the reaction was neutralized with $1 \mathrm{~N} \mathrm{HCl}$ solution. The reaction mixture was extracted twice with EtOAc, the combined organic layers were washed with brine, dried with anhydrous sodium sulfate and evaporated to give compound $\mathbf{S 1 1}$ (2.2 g, 92.3\%). ${ }^{1} \mathrm{H}$ NMR $\left(500 \mathrm{MHz}, \mathrm{CDCl}_{3}\right) \delta=7.56(\mathrm{~d}, \mathrm{~J}=7.9 \mathrm{~Hz}, 1 \mathrm{H}), 7.49(\mathrm{~d}, \mathrm{~J}=1.9 \mathrm{~Hz}, 1 \mathrm{H}), 7.23(\mathrm{dd}, \mathrm{J}=7.9$, $1.9 \mathrm{~Hz}, 1 \mathrm{H}), 6.20(\mathrm{~d}, \mathrm{~J}=1.6 \mathrm{~Hz}, 2 \mathrm{H}), 4.16-4.10(\mathrm{~m}, 4 \mathrm{H}), 4.08-4.00(\mathrm{~m}, 4 \mathrm{H}), 2.97$ (t, J = 7.9 Hz, 2H), $2.67(\mathrm{t}, \mathrm{J}=7.9 \mathrm{~Hz}, 2 \mathrm{H}) .{ }^{13} \mathrm{C}$ NMR $\left(500 \mathrm{MHz}, \mathrm{CDCl}_{3}\right) \delta=178.19,141.15,136.14,134.20$, $128.94,126.47,125.91,100.68,100.62,65.26,35.28,30.38$. HR-ESI-MS (m/z): calcd for $\mathrm{C}_{15} \mathrm{H}_{18} \mathrm{O}_{6}[\mathrm{M}+\mathrm{H}]^{+}: 295.1176$, found: 295.1507 . 


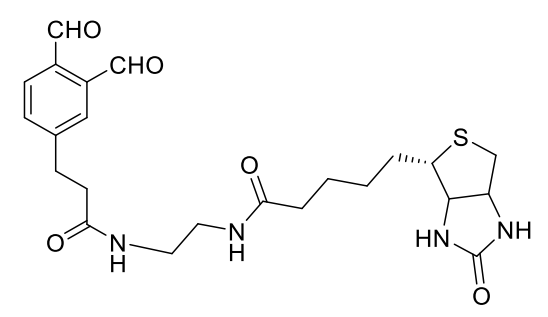

To a $25 \mathrm{~mL}$ round bottom flask, compound $\mathbf{S} 1 \mathbf{1}(200 \mathrm{mg}, 0.68 \mathrm{mmol}), N$-biotinyl-ethylenediamine hydrochloride salt $(212 \mathrm{mg}, 0.66 \mathrm{mmol})$ were added, followed by HATU (260 mg, $0.68 \mathrm{mmol})$. Anhydrous DMF $(10 \mathrm{~mL})$ was added under argon, and followed by the DIEA (356 $\mu \mathrm{L}, 2 \mathrm{mmol})$. The reaction was stirred at room temperature for overnight. After concentration under vacuo, the residue was diluted with ethyl acetate $(500 \mathrm{~mL}$ ). The solution was washed with $1 \mathrm{~N} \mathrm{HCl}$ (aq.), sat. $\mathrm{NaHCO}_{3}$ (aq.) and brine. The organic phase was dried over anhydrous sodium sulfate, then the solvent was removed under vacuum. The crude compound was treated with TFA (with $5 \% \mathrm{H}_{2} \mathrm{O}$ ) and stirred at room temperature for $2 \mathrm{~h}$. The mixture was then evaporated under vacuo, and followed by reparative HPLC purification $\left(20 \%-75 \% \mathrm{ACN} / \mathrm{H}_{2} \mathrm{O}\right.$ with $0.1 \%$ TFA over 45 $\mathrm{min}$ ), then concentrated under vacuum and lyophilization to compound $\mathbf{S 1 2}$ (63.9 $\mathrm{mg}, 20.2 \%)$.

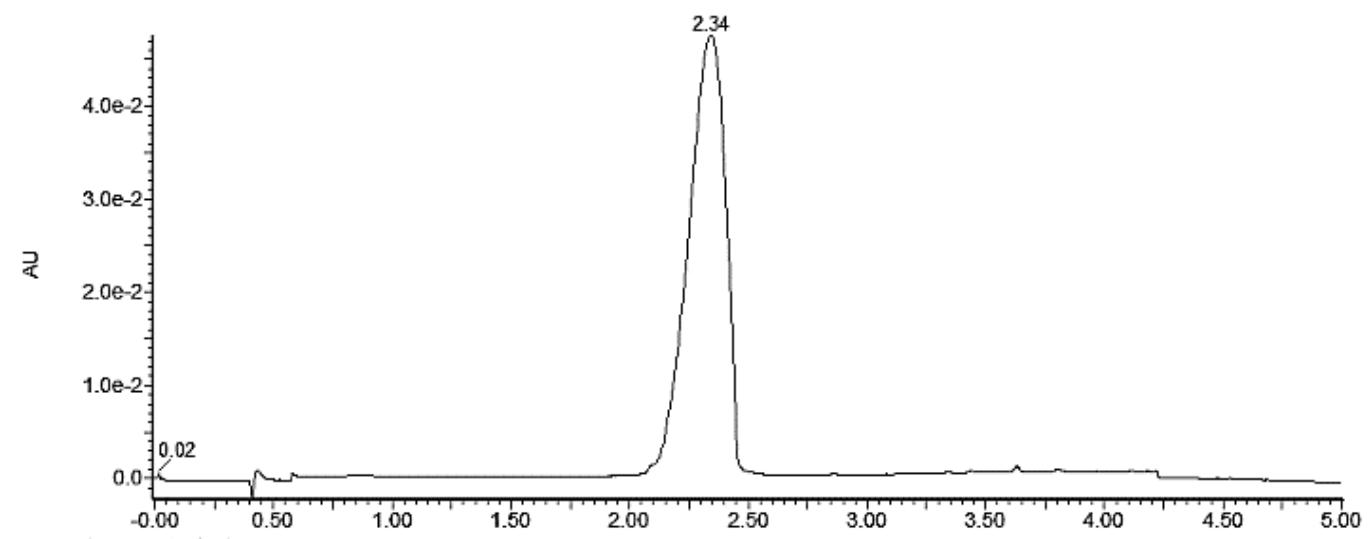




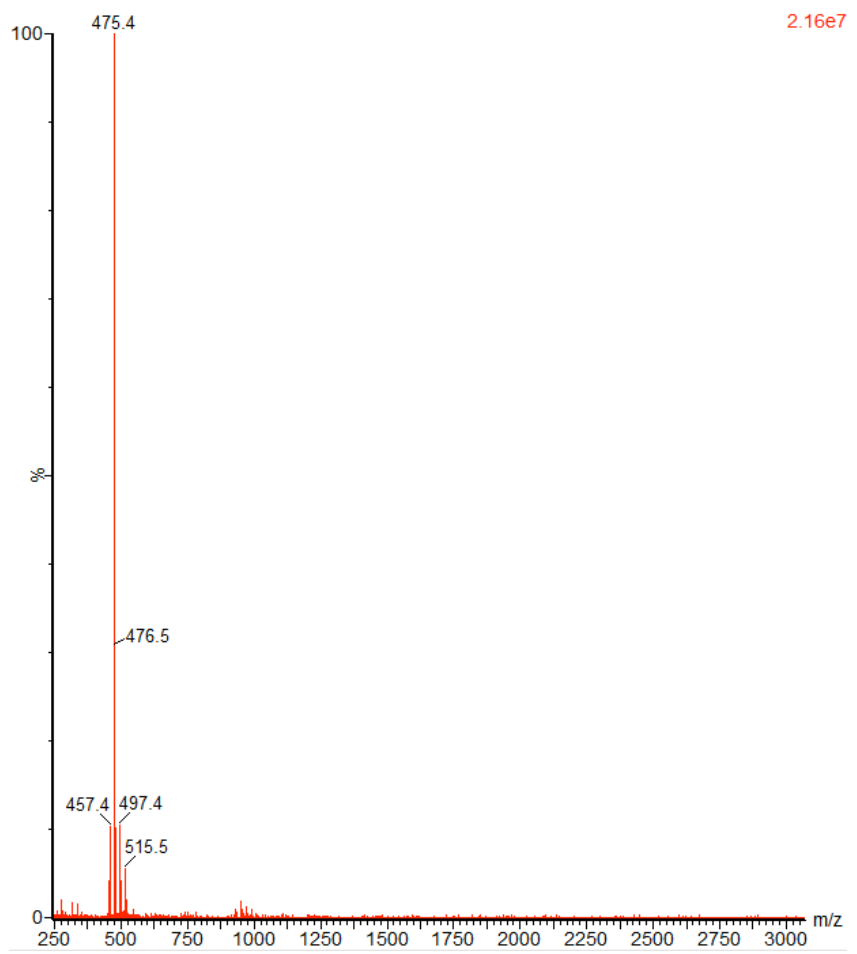

Supplementary Figure S2.3.5. UV trace and corresponding MS from LC-MS analysis of the compound after purification. Gradient: $5 \%-95 \% \mathrm{ACN} / \mathrm{H}_{2} \mathrm{O}$ with $0.1 \%$ TFA over 5 min at a flow rate of $0.4 \mathrm{~mL} / \mathrm{min}$. ESI-MS calcd for $\mathrm{C}_{23} \mathrm{H}_{30} \mathrm{~N}_{4} \mathrm{O}_{5} \mathrm{~S}[\mathrm{M}+\mathrm{H}]^{+} \mathrm{m} / z=475.20$, found 475.40 . 
III. NMR Spectra

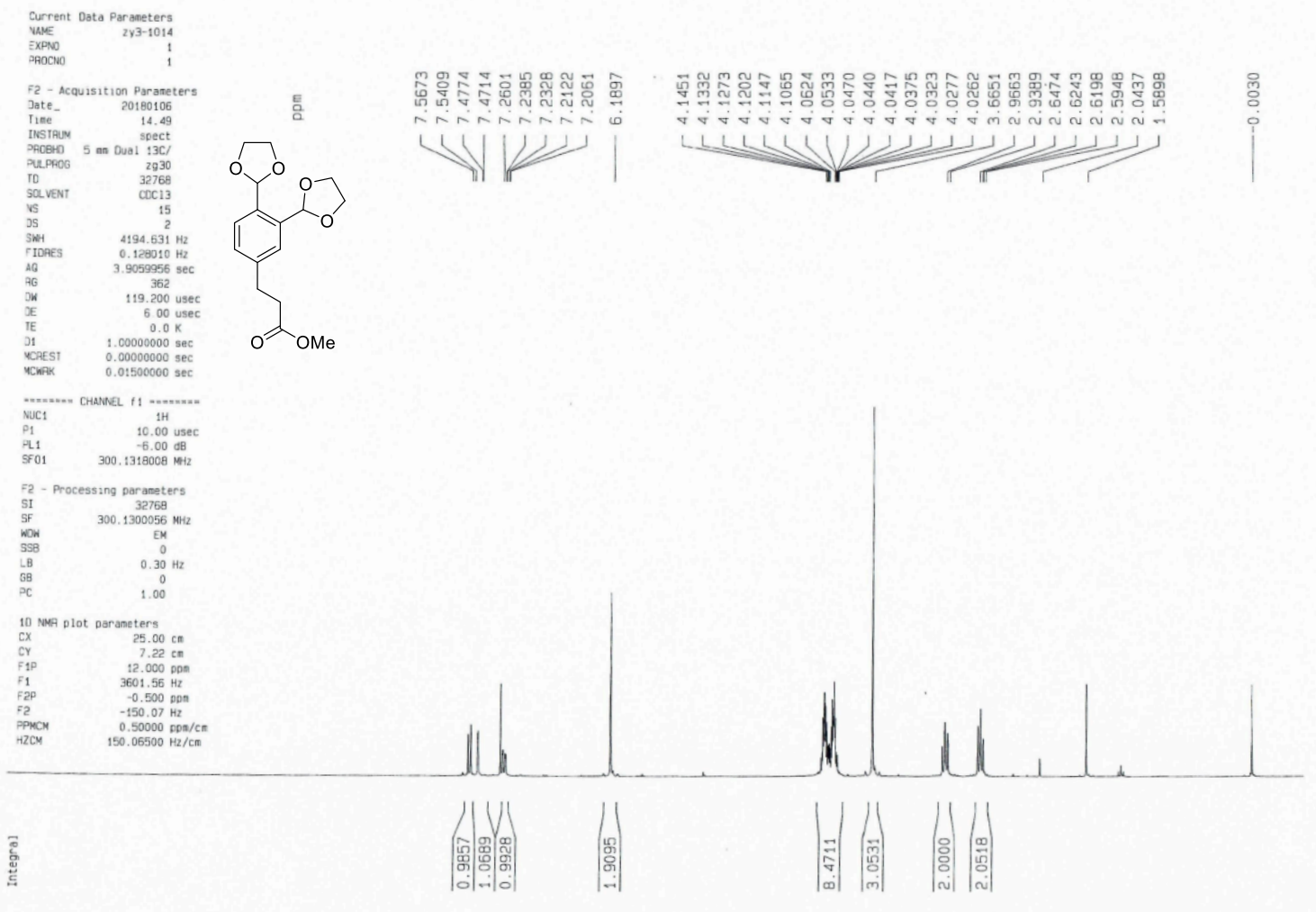

$\mathrm{ppm} \mathrm{l}_{11}$

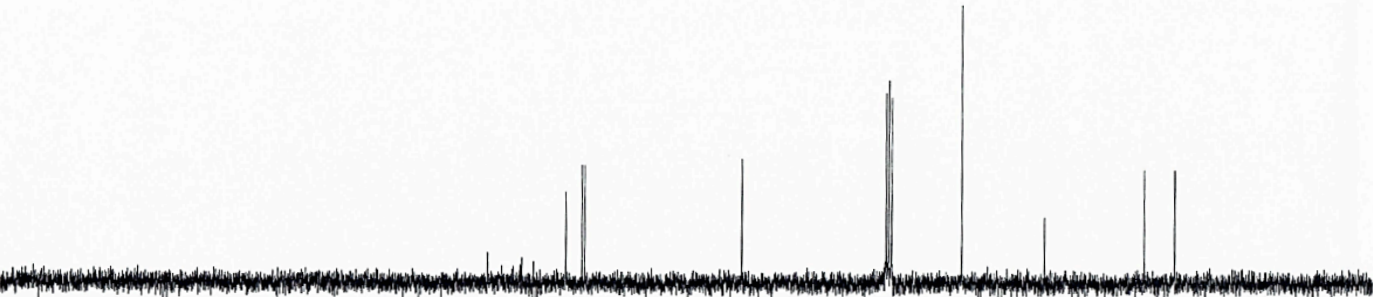
ppm 

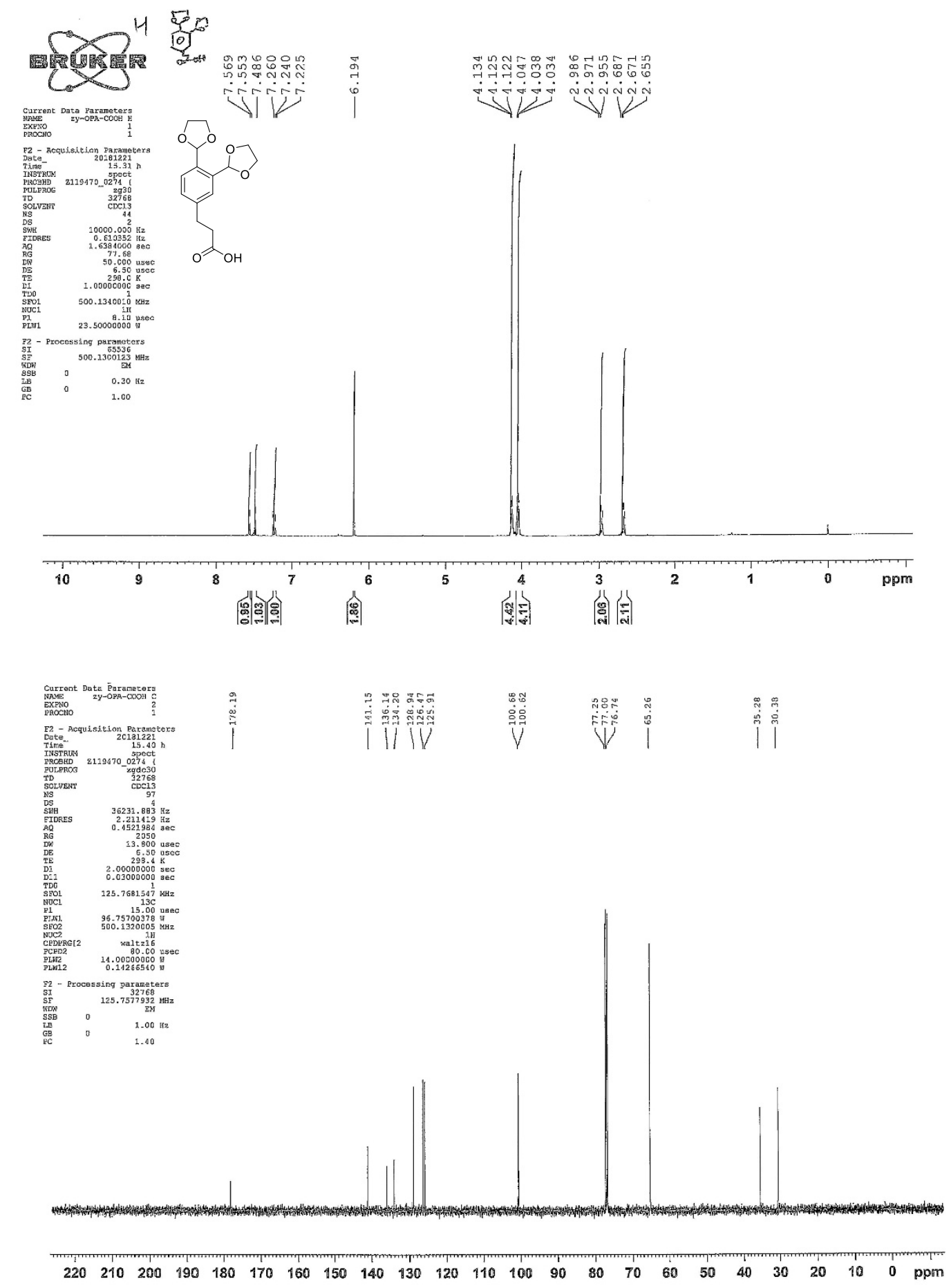


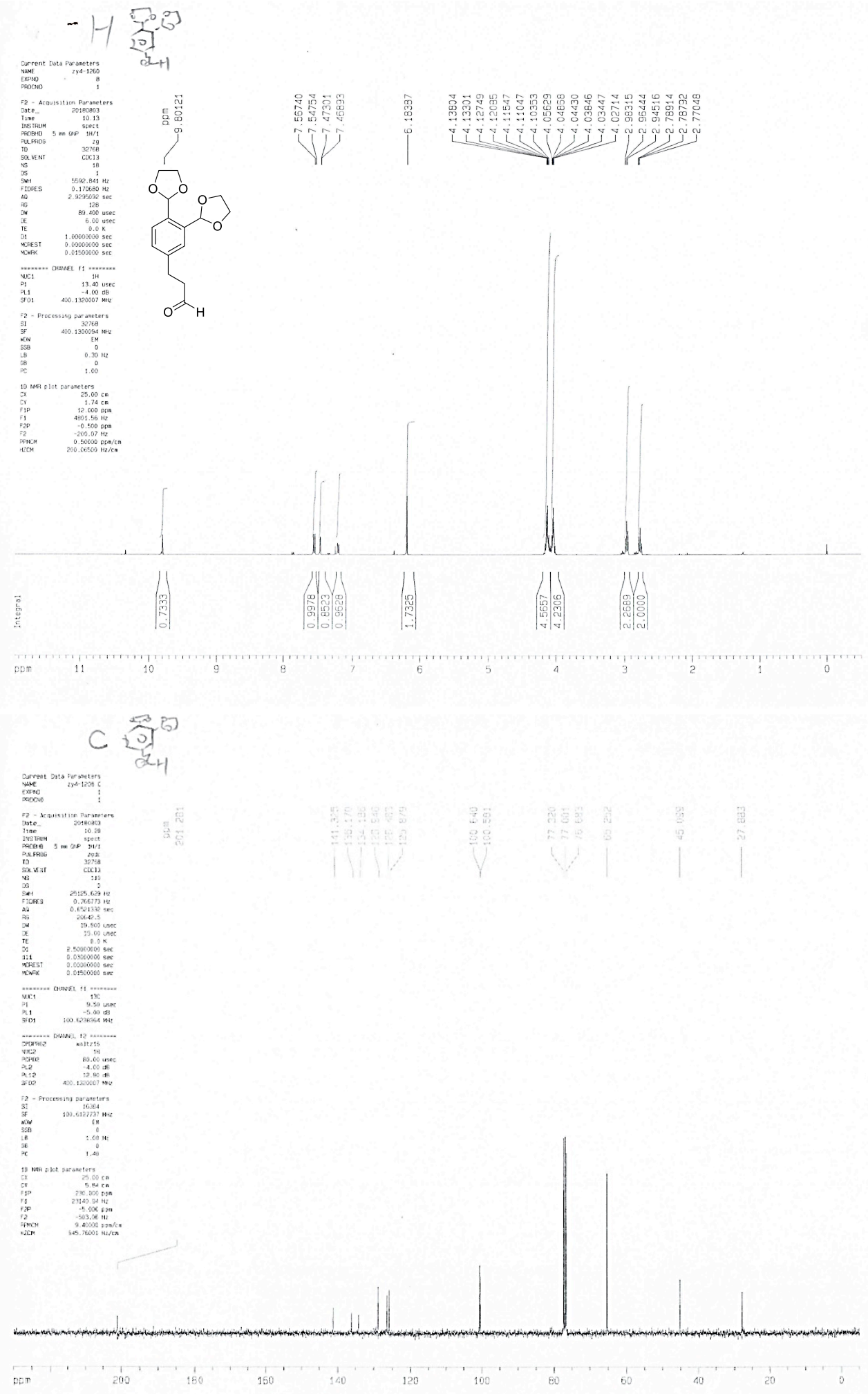




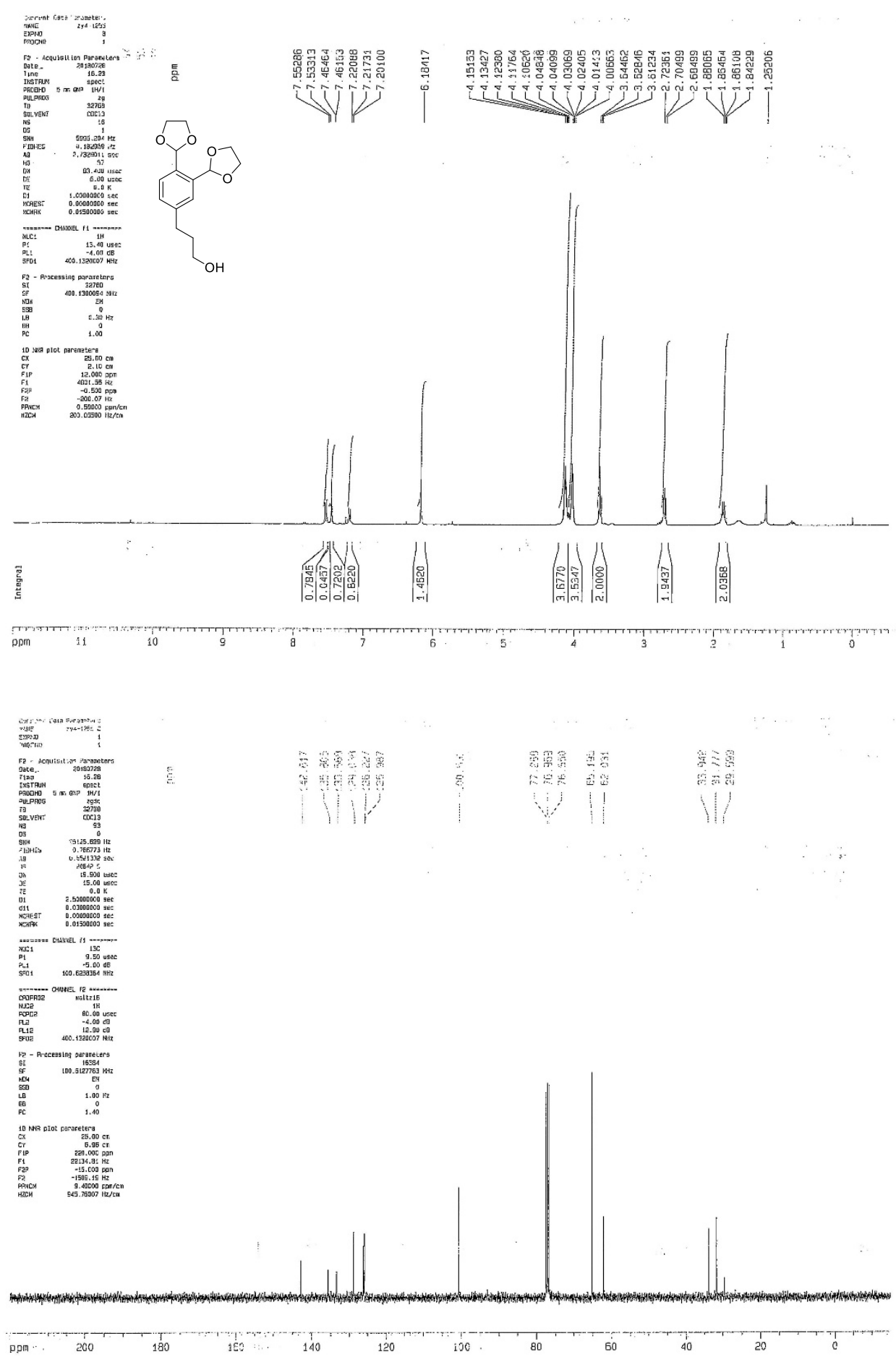




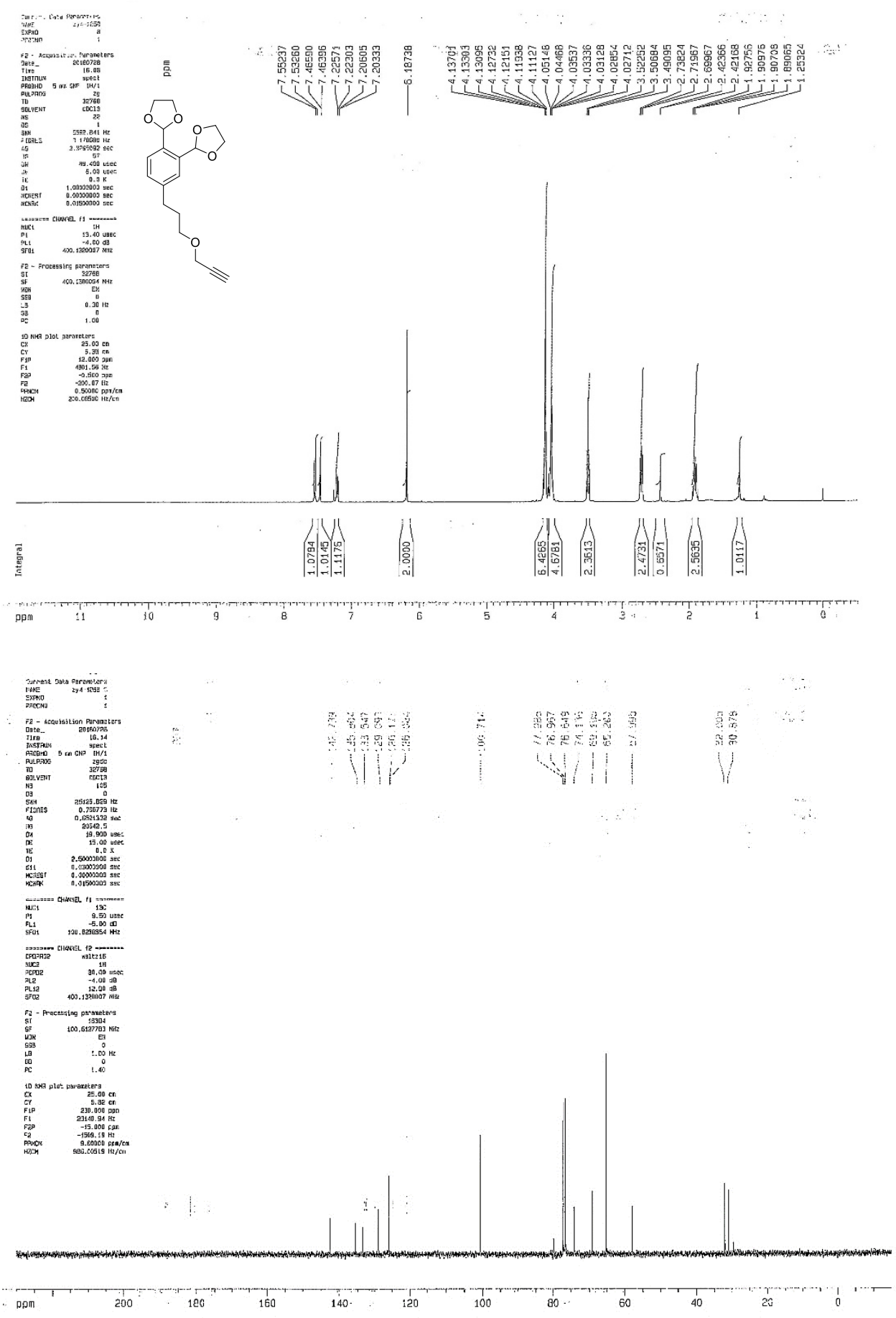



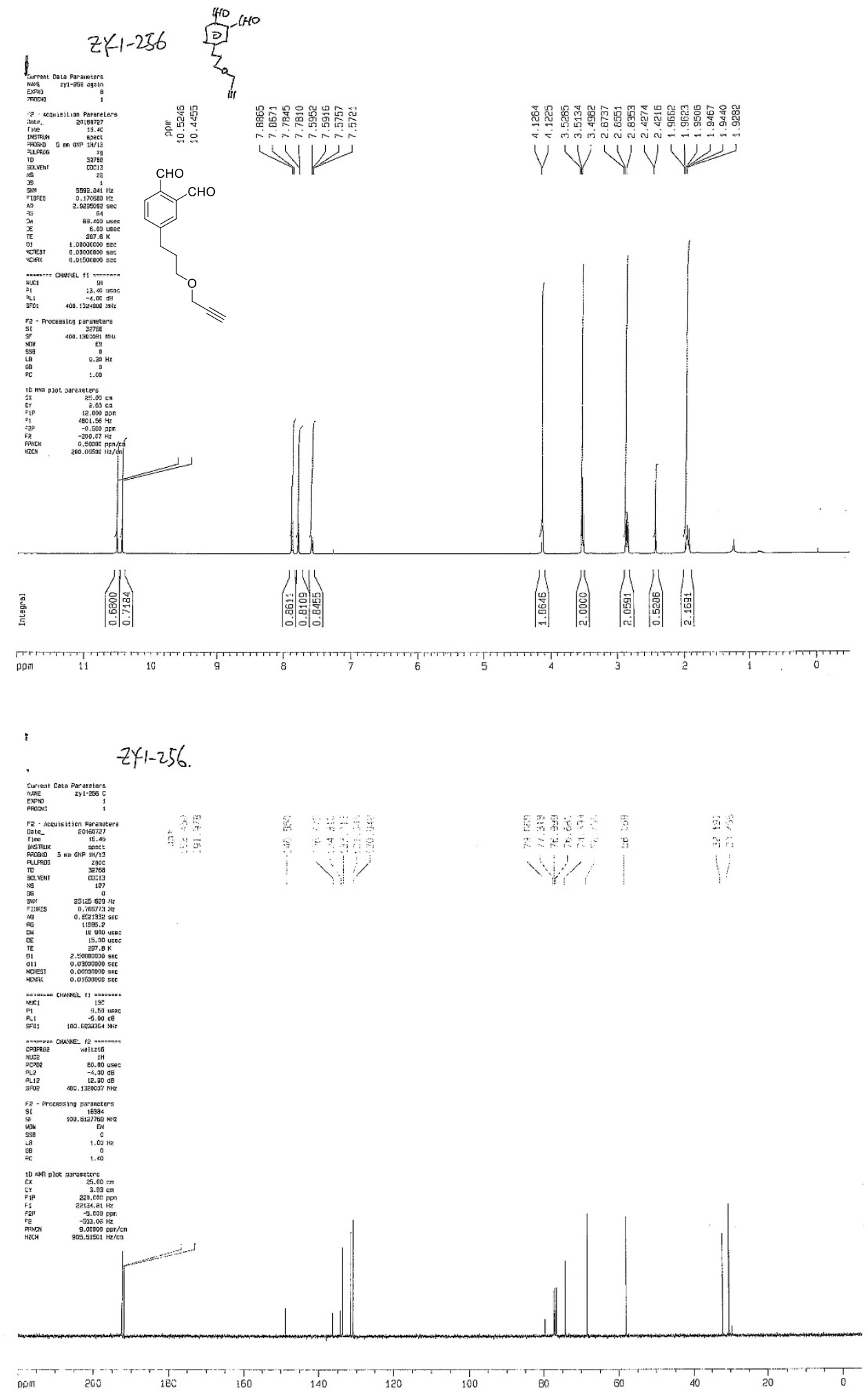

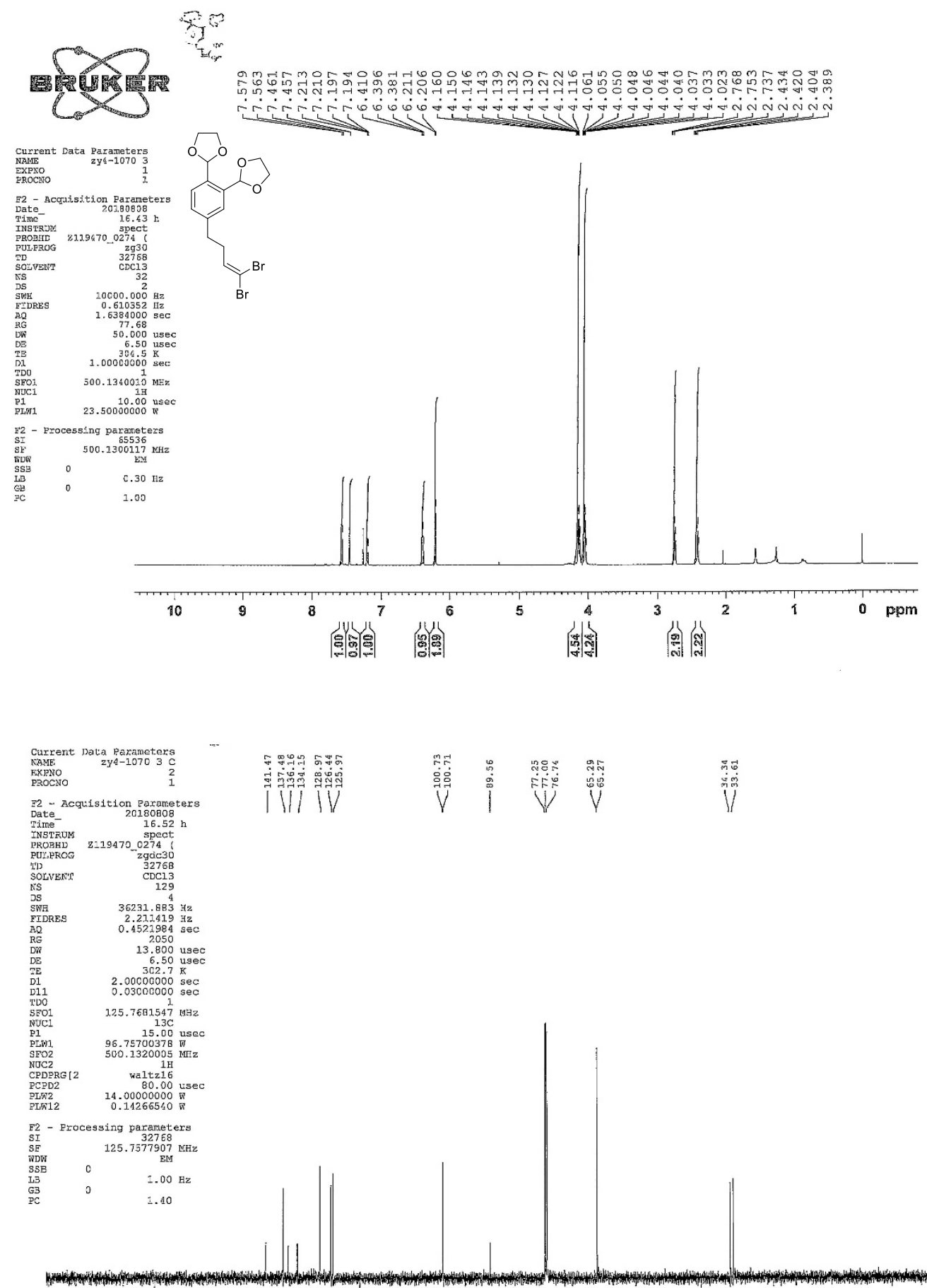

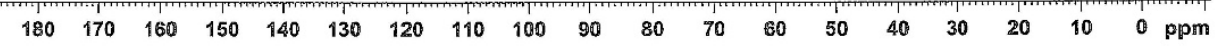



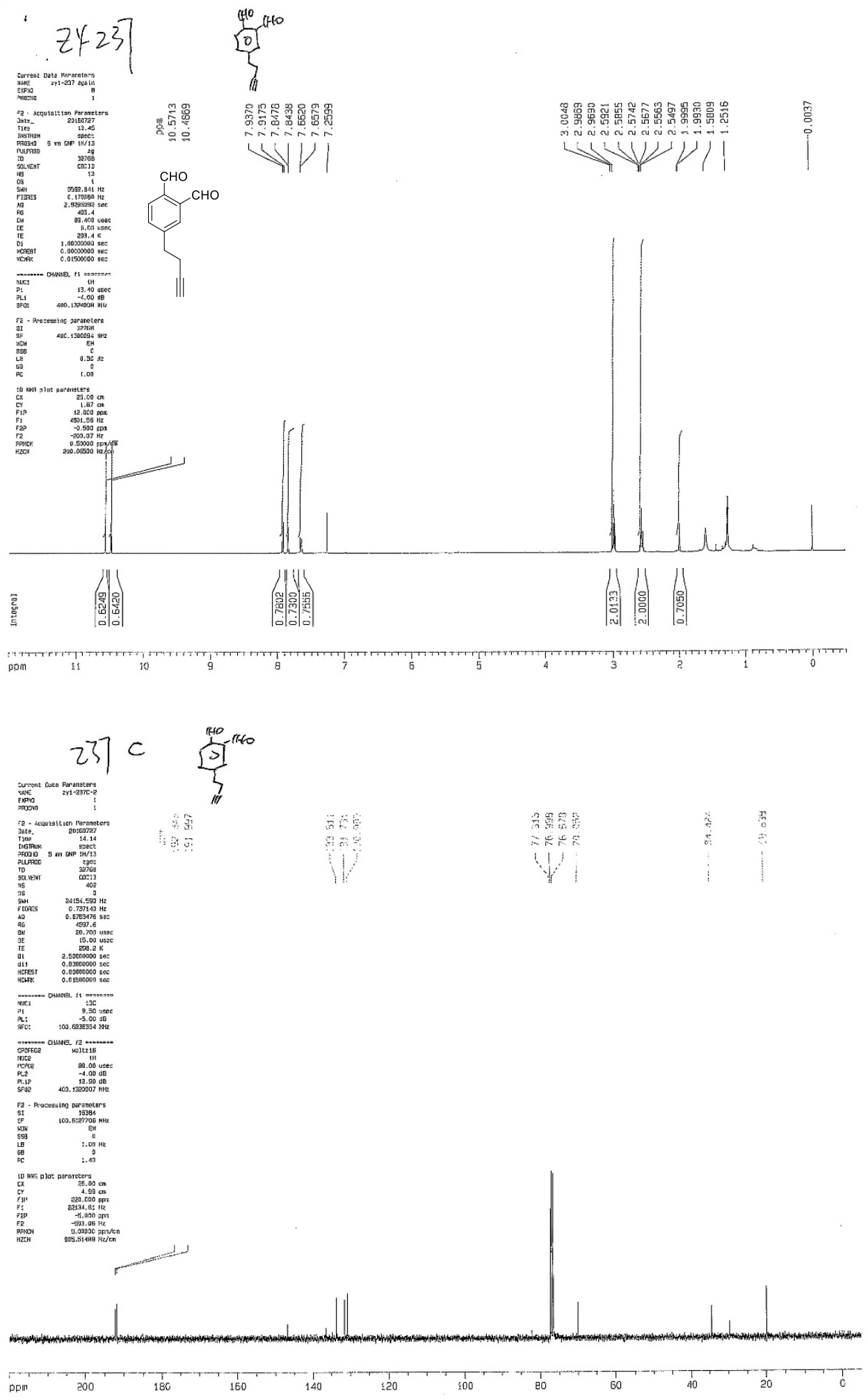


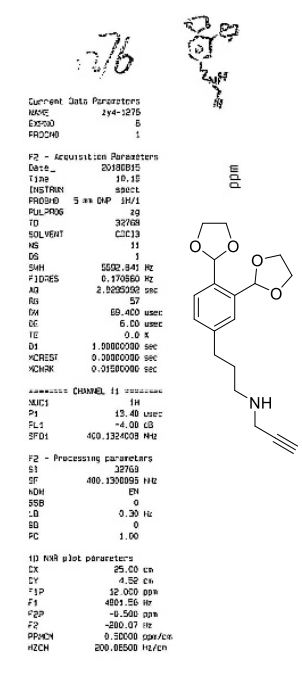

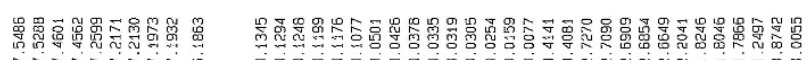
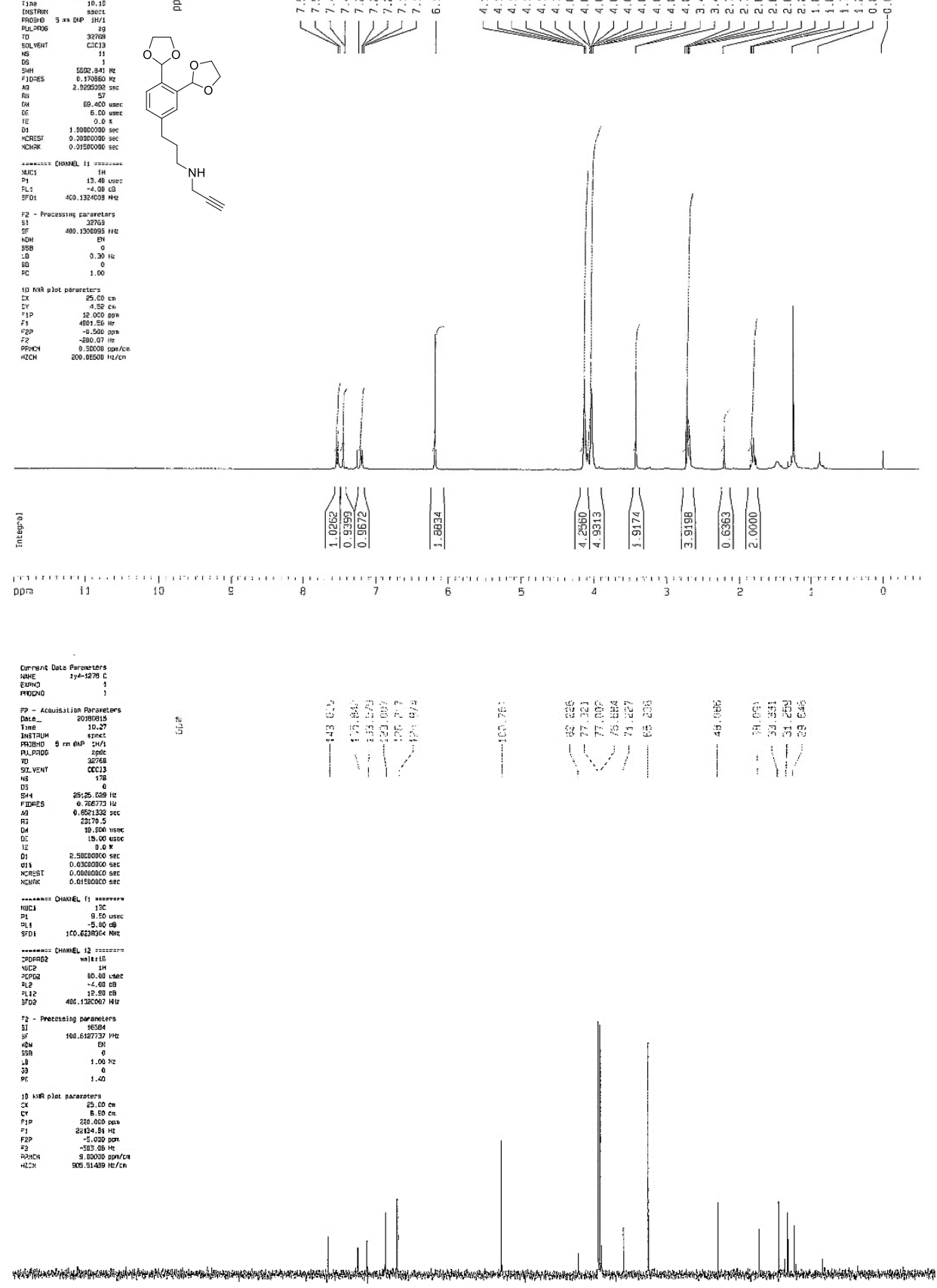

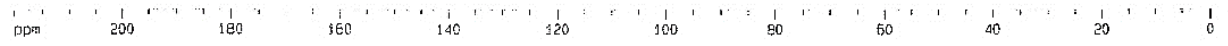



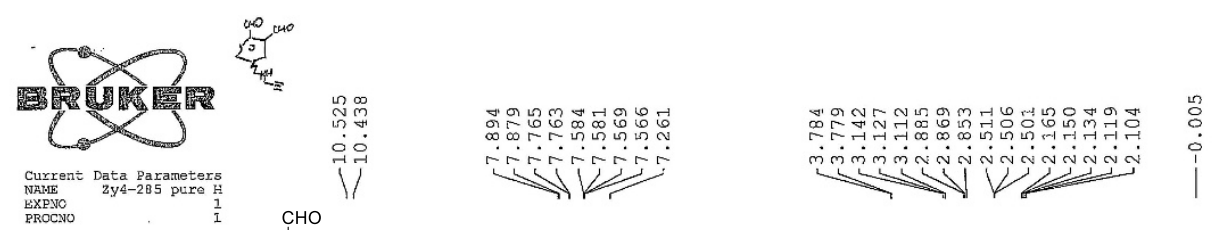

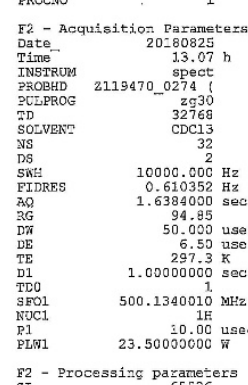

$\mathrm{P} 2$
$\mathrm{SI}$
$\mathrm{SF}$

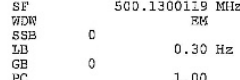

$\mathrm{CHO}$

CHO
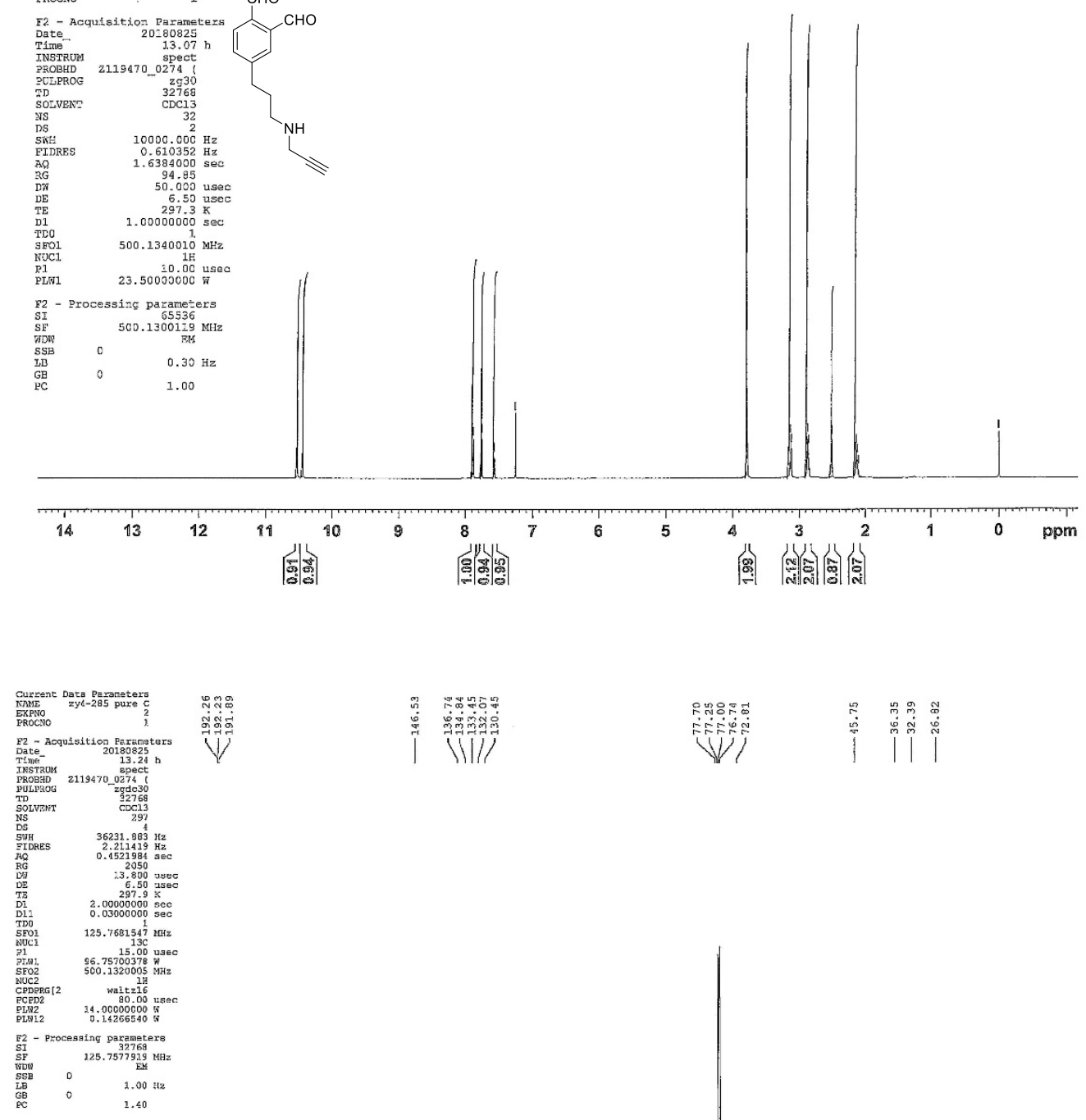

$\sqrt{\sqrt{2}}$

V|

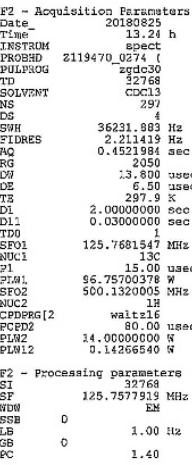
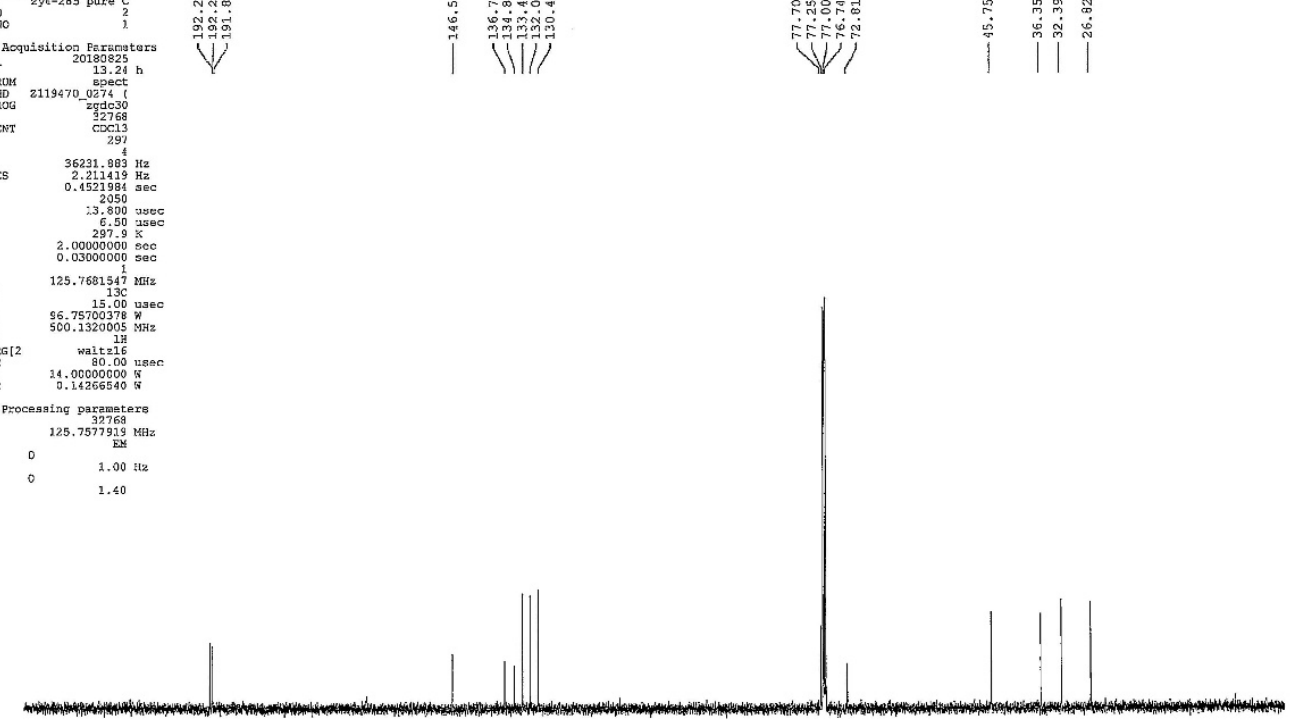

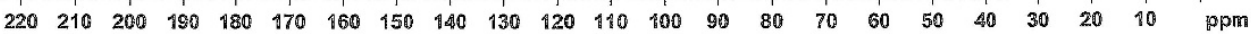



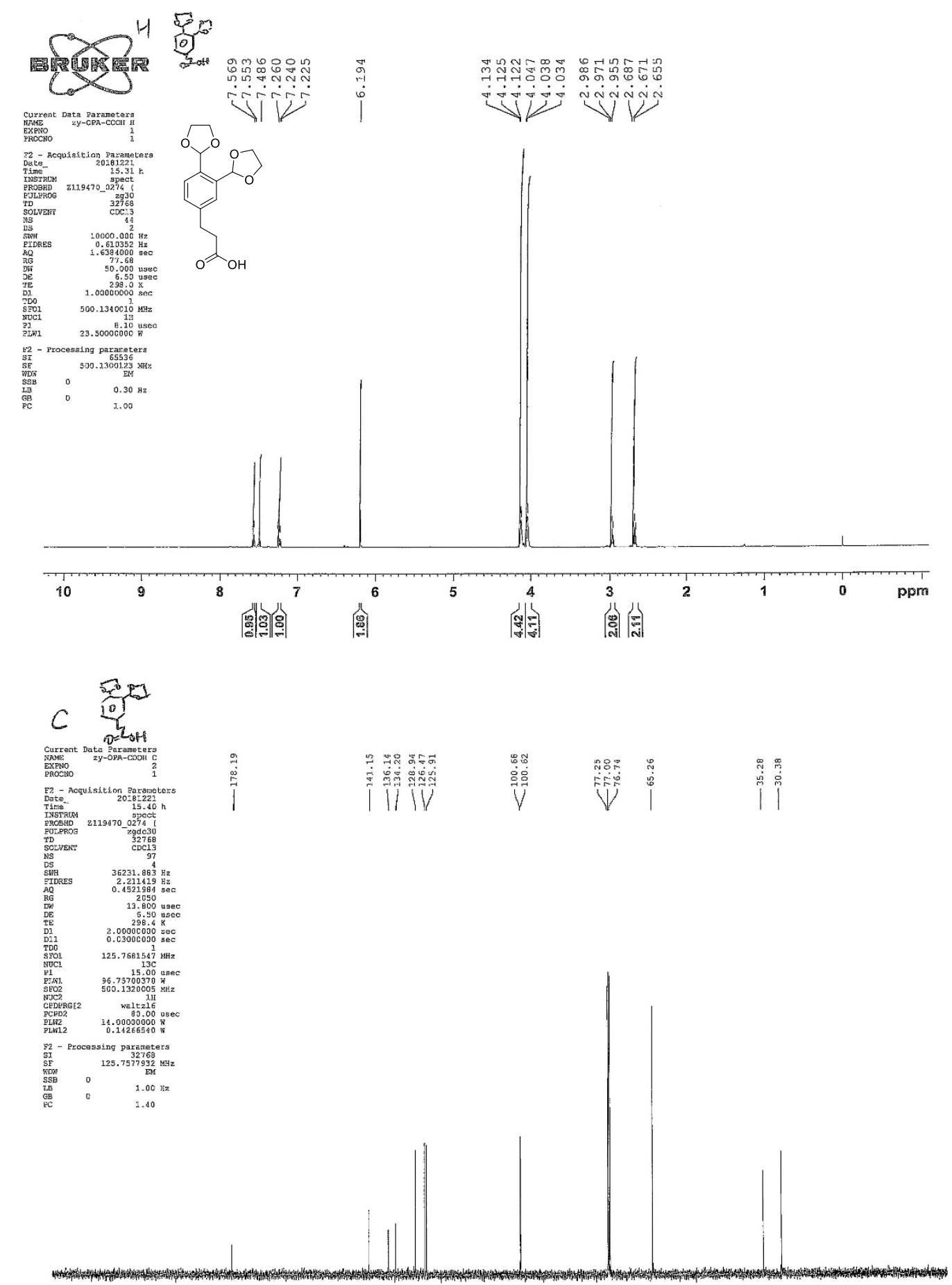

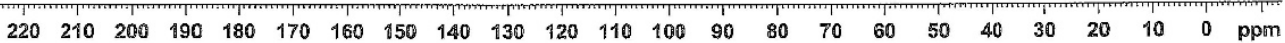




\section{Reference:}

[1]: Nguyen, Trung, and Matthew B. Francis. (2003) Practical synthetic route to functionalized rhodamine dyes. Org. Lett. 5, 3245-3248.

[2]: Cox, Jürgen, and Matthias Mann. (2008) MaxQuant enables high peptide identification rates, individualized ppb-range mass accuracies and proteome-wide protein quantification. Nat. Biotechnol. 26, 1367.

[3]: Tyanova, Stefka, Tikira Temu, Pavel Sinitcyn, Arthur Carlson, Marco Y. Hein, Tamar Geiger, Matthias Mann, and Jürgen Cox. (2016) The Perseus computational platform for comprehensive analysis of (prote) omics data. Nature methods. Nat. Methods. 13, 731.

[4]: Tung, C. L.; Wong, C. T.; Fung, E. Y.; Li, X. (2016) Traceless and chemoselective amine bioconjugation via phthalimidine formation in native protein modification. Org. Lett. 18, $2600-2603$. 